\title{
Power, Food and Agriculture: Implications for Farmers, Consumers and Communities
}

\author{
University of Missouri \\ College of Agriculture, Food \& Natural Resources \\ Division of Applied Social Sciences Working Paper
}

Mary K. Hendrickson

University of Missouri

Philip H. Howard

Michigan State University

Douglas H. Constance

Sam Houston State University

Paper posted November 1, 2017

Division of Applied Social Sciences

215 Gentry Hall

Columbia, MO 65211

http://dass.missouri.edu/
要

College of Agriculture, Food \& Natural Resources University of Missouri 


\begin{abstract}
:
One of the most pressing concerns about the industrialization of agriculture and food is the consolidation and concentration of markets for agricultural inputs, agricultural commodities food processing and groceries. In essence a small minority of actors globally exercise great control over food system decisions. This means that because of increased consolidation of these markets globally - from the United States to China to Brazil, from South Africa to the United Kingdom the vast majority of farmers, consumers and communities are left out of key decisions about how we farm and what we eat. Transnational agrifood firms are motivated by profits and power in the marketplace, leaving other social, economic and ecological goals behind. This creates an agroecological crisis in the face of climate uncertainty but one that is rooted in social and economic organization. In this chapter we detail the current economic organization of agriculture, and briefly describe its negative impacts on farmers, communities and ecology. We conclude by articulating stories of farmer-led resistance that imagine a new food system.
\end{abstract}




\section{Introduction}

The system by which most relatively affluent global consumers obtain their food is globalized and industrialized in the same fashion as the rest of the global capitalist system. An increasingly smaller number of actors within global supply chains make many of the decisions about the food we eat, from where and how it is grown to how we will obtain it. While this system has produced and marketed a great many tasty and diverse calories for those who can afford to participate, the costs of this system have been borne by farmers, food workers, rural communities and the ecology in which we are all embedded. In the way it is shaped and organized, the food system is very much like other industries, but food (and water) is unlike other consumer goods. Everyone on the planet needs to eat nutritious foods every day to live a healthy and productive life. Thus, we believe food should not be treated like other commodities, and the people who produce food, along with a stable agroecosystem, should be protected as critical to society.

The purpose of this chapter is to show how a minority of global actors make many of the decisions about what food is produced - where, how, by whom and for whom - and highlight the implications of these decisions for farmers, consumers, communities and their environment. The structuring of the relationship along the supply chain from farm to plate, and the globalizing of these relationships, has frequently harmed our ecology, rural communities, and the economic livelihoods of farmers and food workers. We explain how farmers and consumers - who often have myriad concerns about the implications of the emerging system of food production - are mostly shut out of systems of decision-making through the continued consolidation of critical points of the supply chain. Instead, decisions are increasingly made by CEOs to meet the narrow demands of shareholders of global agrifood firms, whose main concern is to increase their power 
more than similar firms. We briefly explore some of the consequences of these decisions for farmers, rural communities and our ecology. Still, farmers and consumers in the U.S. and globally are not passive bystanders to consolidation and centralization trends and have organized in multiple ways to stop, shape or opt-out of them.

\section{Social and Economic Organization of the Food System Has Real Life Impacts}

The organization of the agricultural and food system has important consequences for the life chances of farmers, farm and food workers, communities and the environment. In the last 50 years, we have reorganized food and farming in the U.S. and across the world towards an industrialized system that reduces food - a physiological necessity that has important cultural and social meanings - to a commodity to be produced as cheaply as possible and sold to the highest bidder. Even the comparative wealthy (by world standards) farmers in the U.S., Canada and Europe end up as relatively powerless participants in food chains over which they have little or no control. Farmers face limited choices in which inputs to use, which crops or livestock to produce, and what markets to sell into. Meanwhile food and farm workers are some of the most food insecure in a country where one in eight households may not know where their next meal is coming from (Coleman-Jensen et al. 2016). That a highly industrialized and capitalized food system can produce a great number of calories and still leave hungry people, many of them involved in the production of food, shows that the tradeoffs farmers, workers and the environment are making are not worth the cost to people, communities and the ecosystem in which we are embedded. Here we review the scholarship that examines concerns and documents impacts of a concentrated and consolidated agrifood system as a way to prepare readers to fully understand the results section, in which we describe the structure in which farmers of all kinds are embedded. 
Let's start with the fact that fewer farmers are able to make a full-time living from farming. For instance, just 40 percent of the two million farms in the U.S. list farming as the primary occupation of the farm operator. Less than ten percent of American farms, or 185,346 farms, are classified as "commercial" by USDA, meaning that they have gross farm sales exceeding \$350,000. At first glance, this "upper 10 percent" of farm households appear to be doing well in the current food and farming system, having a median net farm income of over $\$ 146,000$ in in 2015 and median household income nearing \$200,000 or 3.5 times the median U.S. household income (Posey 2016; USDA 2015b). Perhaps more concerning, 30 percent of farm households listing farming as a principal occupation reported a median of just \$788 in farm income in 2015. (We should note, however, these farm households reported total household median income just over that for all U.S. households because of the contribution of off-farm income (USDA 2015b)).

\begin{tabular}{|c|c|c|c|c|}
\hline Item & $\begin{array}{l}\text { Residence } \\
\text { Farms }\end{array}$ & $\begin{array}{c}\text { Intermediate } \\
\text { Farms }\end{array}$ & $\begin{array}{c}\text { Commercial } \\
\text { Farms }\end{array}$ & All Farms \\
\hline Number of farms & $1,215,011$ & 631,942 & 185,346 & $2,032,300$ \\
\hline & \multicolumn{4}{|c|}{ Income, median dollars per household } \\
\hline Farm income & $-2,100$ & 788 & 146,466 & -765 \\
\hline Off-farm income & 82,987 & 55,750 & 40,250 & 67,500 \\
\hline Earned Income & 62,500 & 31,789 & 22,500 & 38,270 \\
\hline Unearned Income & 24,000 & 25,013 & 9,000 & 25,013 \\
\hline Total household income & 82,925 & 59,102 & 197,980 & 76,735 \\
\hline
\end{tabular}

These changes exact real tolls on farmers. In the early 2000s, when Midwestern commodity agriculture was reeling from low prices, a Missouri farmer told Hendrickson that 'I used to look around to see if any farmers were getting out of farming so I could get their land to 
farm. Now I look around and see I have no neighbors.' As one can see in Table 1, three-fifths of U.S. farms are residential farms where the operator does not consider farming as their primary occupation, while about a tenth gain significant income from farming, leaving a floundering "intermediate" set of farms. Some of these farms may be considered part of the declining "Agriculture of the Middle" (Lyson, Stevenson, and Welsh 2008), defined as the decrease in the number of farms in mid-sized categories (USDA uses $\$ 350,000$ to $\$ 999,999$ in annual agricultural sales). Only 118,000 such farms remained in the 2012 Census of Agriculture (USDA 2015a). While fewer than six percent of all U.S. farms, they accounted for about onefifth of all agricultural sales and farmland, and over one quarter of net farm income. Farmers of the middle are often left out by the large commodity chains we describe in the results section, but also find fewer other mid-range businesses to cooperate with (mid-range processing plants, midsized distributors, or mid-sized grocers) or to supply them with inputs and right-sized equipment for planting, harvesting, storing, processing or distributing their product (Legun and Bell 2016).

Given difficult economics, farmers of the middle, or farms in USDA's "intermediate" category, are precisely those who may feel particular pressures to farm in ways incongruent with their values or beliefs. For instance, James and Hendrickson (2008) found evidence from Missouri farmers to suggest that financial pressures can increase a farmer's willingness to tolerate unethical conduct. Concentrated markets may cause farmers to feel financially pressured, especially as they become relatively dependent within production networks organized by transnational agrifood firms (Hendrickson, James, and Heffernan 2013). Hendrickson and James (2005) argue that concentrated markets for inputs or agricultural products narrow the range of choices that farmers can make about how they treat their land, animals, and workers, and even what kind of farming they decide to enter. For instance, a farmer may want to enhance 
soil quality by practicing multiyear rotations with three to five different crops but is prevented because they can't find regional markets for sunflowers or wheat rather than just soybeans and corn (Roesch-McNally et al. 2017). Farmers may also want to practice diversified crop and livestock farming but cannot find available markets for smaller numbers of livestock. For example, it is essentially impossible for Midwestern farmers who want to use non-genetically modified soybeans to access seeds and genetic materials that don't contain any GM traits, as

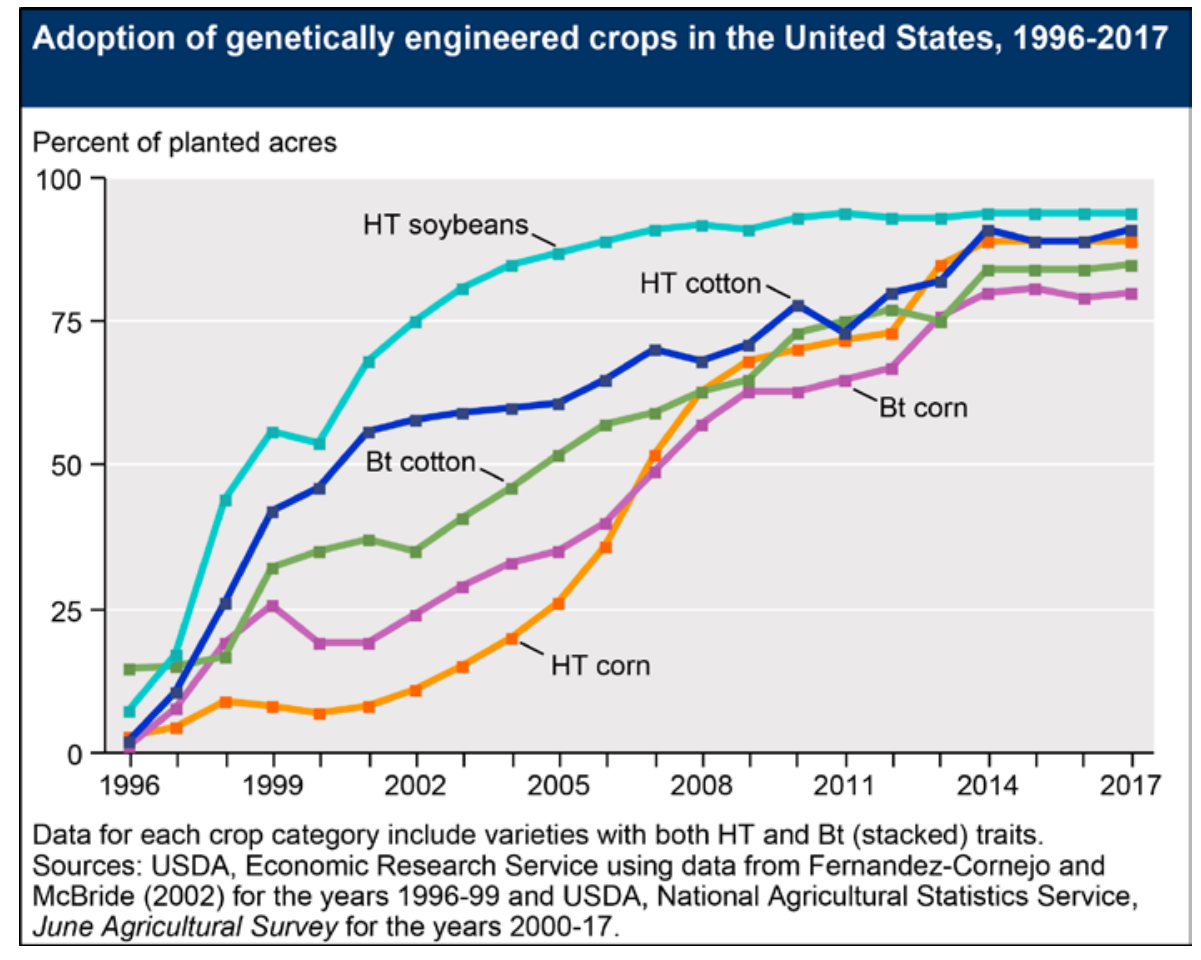

nearly 100 percent of soybeans now contain at least one herbicide tolerant trait (see figure 1).

Stuart and Schewe (2016) document that seed corn contracts in Michigan constrain the choices of farmers causing them to over-apply fertilizer to maximize yield, resulting in greenhouse gas emissions and water pollution, while Stuart (2009) found that farmers in the Central Coast of California felt pressured by their buyers to use practices they felt were ecologically destructive and unethical. In short, research has suggested that constrained choices can force farmers into the 
"kinds of decisions that they otherwise would not have chosen for ethical or other reasons" (Hendrickson and James 2005, 283)

The decisions these farmers must make also impact their communities. Scholars have long been interested in how the social and economic organization of food and farming impacts farmers AND communities. Walter Goldschmidt's (1978) seminal study of California agricultural organization in the 1940s found industrialized agriculture had adverse community effects while smaller-scale family operated farms were associated with diverse economies and egalitarian social structures (see for example Heffernan, 1984; Lobao 1990; and Lyson 2004). In their meta-analysis on the relationship between agricultural structure and community well-being, Lobao and Stofferahn (2007) found detrimental effects of industrialized farming on communities were reported in 82 percent of 51 studies. These negative effects included greater income inequality or poverty; decreased retail trade and diversity of retail firms; population declines; and negative health effects of large livestock operations. Of course, it's not only farmers and rural communities who are impacted by changes in food and farming. Howard (2016a) shows how food retail concentration has left many urban neighborhoods without access to affordable nutritious foods, and argues that food processing and retail concentration has resulted in fewer good jobs and worse treatment of farm and food labor.

Along with farmers and communities, the ecology in which human society is embedded has not been spared the negative impacts of the way we produce and consume food. The organization of the agricultural marketplace, for instance, forces many U.S. farmers into specialized monocultures and separates livestock from crop production both at the farm level and at larger regional geographies (Lyson 2004). Livestock waste in these systems becomes an environmental pollutant rather than a recyclable resource contributing to soil health and fertility. 
Specialized markets mean that corn and soybeans become the de facto crop rotation across large portions of the Corn Belt, which can result in sizable soil loss. To illustrate, soil erosion in Iowa costs its farmers $\$ 1$ billion per year (Eller 2014), and also causes nutrient run-off that contributes to the Dead Zone in the Gulf of Mexico (one ton of eroded Midwestern soil can contain over two pounds of nitrogen and one pound of phosphorus). ${ }^{1}$ Soil health advocates encourage farmers to plant cover crops (keeping the soil covered and feeding the soil food web), to reduce tillage as much as possible, and to increase plant diversity. However, fewer farmers are on the land farming larger acreages making the labor and timing of cover crops challenging. Few if any markets exist for diversified crops and livestock meaning crop rotations are limited, and input suppliers are oriented to providing seeds, chemicals and equipment for the dominant crops in their region.

The use of herbicides and pesticides in agriculture, combined with mechanization, have reduced the number of people needed to farm large acreage. Nature is dynamic however, and weeds and pests have rapidly evolved resistance to widely used chemicals. The introduction of herbicide tolerant crops has magnified this problem in the last 20 years (see list of herbicide resistant weeds at www.weedscience.org). Row crop farmers in the Southeast and Midwest have been scrambling in recent years to control a specific herbicide resistant pigweed (Amaranthus palmeri), which thrives particularly well in a rapidly changing climate, and has a thick woody stalk that causes havoc to farmers' machines. In 2015, Monsanto introduced dicamba-tolerant soybeans and cotton as a way to control this and other resistant weeds; the problem is that dicamba can drift when applied in anything less than perfect application conditions, causing damage to a wide range of crops. ${ }^{2}$ In 2016 and 2017, this damage caused considerable tension in rural communities, often pitting neighbor against neighbor; conflict over dicamba damage was 
cited in the murder of an Arkansas farmer by a neighboring Missouri farmhand. ${ }^{3}$ One can only imagine the economic and social pressures that manifested in that confrontation, or the ethical conflict over farming choices that may have led to the situation.

Such ecological impacts can change risk and resilience equations for farmers, communities and consumers. Resilience is generally defined as the ability of ecosystems and communities to decrease their vulnerability to sudden shocks, and to generate - through relationships and processes - options for adaptive change. The industrialization and consolidation of agriculture, occurring within a remarkable period of stable, temperate climate (King 2008), has increased vulnerability for many farmers and communities and reduced the range of options for adaptation from field to plate (Hendrickson 2015). With its lengthening supply chain, the industrialization and concentration of the agrifood system results in a lack of tight ecological and social feedback loops, compromising adaptive responses that promote resilience (Lamine 2015). For instance, changes that that took place in the Australian dairy sector after it was deregulated to orient itself towards competing in the global marketplace increased competition between producers, which combined with the increasing power of supermarkets to dictate terms, led "producers to manage a system that carries increased risk in the physical environment and to animal health and welfare because of higher stocking rates and production per cow” (Sinclair et al. 2014, 379). Constrained choices for how farmers can manage their agroecosystems in relation to the structure of the markets they participate in leaves little room to maneuver ecologically in the face of the unpredictable temperatures, extreme precipitation events, droughts, and even wildfires occurring as the climate changes. To wit, in 2017, Kansas farmers battled wildfires that burned over 650,000 acres in March, while the first weekend in May saw nearly 20 inches of snow. Both events killed thousands of livestock, while 
the latter flattened a rapidly developing wheat crop. Sustainable agricultural practices can help mitigate damages, but it remains difficult for farmers to prepare for such calamitous weather.

The discussion above points to an industrial agrifood system in crisis regarding its negative economic, social and ecological externalities (Constance et al. 2014a; Howard 2016a; Magdoff et al. 2000). This crisis has accelerated steadily over the past 40 years and has now reached a tipping point based on the realization that industrial agriculture is the major contributor to global climate change. To complicate the scenario, by the year 2050 nine billion people will need to be fed without expanding the agricultural land base, while reducing negative environmental impacts such as greenhouse gas emissions (Gardner 2009; FAO 2009) leading to considerable debate as to the best way to achieve food security for all without destroying our ecosystem. The current economic and social structure of the agrifood system has forced many farmers out of farming as a full-time profession in the U.S. and decimated the number of smallholder farmers in other countries, while those who remain face consolidated markets that narrow the range of choices they can make about what kind of farmer they want to be and how they want to manage land, people and animals. By limiting farmers' ability to manage their farms as an ecosystem (also known as agroecology), this consolidated and industrialized agriculture system has increased their vulnerability and reduced their resilience in the face of emerging threats, such as our changing climate.

\section{Analyzing the Social and Economic Structure of Food and Farming}

Before we turn to documenting the very structure that causes the impacts we describe above, we provide an analytical framework that situates the data in the next section. Many different disciplines have converged around the idea that the current structure of food and agriculture can best be thought of as a series of competing global production networks in which 
actors can be more or less dependent, and thus more or less powerful (Carstensen, Lianos, Lombardi, \& MacDonald, 2016; James, Hendrickson, \& Howard, 2013; Wilkinson, 2006, Hendrickson et al. 2008). A key concept is defining power in the food system, who has it, how we can document and/or measure it, and how it is articulated in the structure that we document. Power is a crucial element of who can make decisions in the food system, decisions which shape the life chances of farmers and workers who produce our food, the vibrancy of the communities in which they live, and the ecology on which future food production depends. In the past, those of us involved in the Missouri School of Agrifood Studies (Bonanno 2009) documented the increase in concentration in different sectors of the agrifood industry in the U.S. through a series of concentration tables, reports, and articles (Constance et al. 2014a). We showed the four-firm concentration ratio in major commodity markets, documented the top four firms in each sector, and illustrated transnational agrifood firm linkages across sectors (Heffernan, Hendrickson, \& Gronski, 1999; Howard, 2009b). We hoped that by documenting the market relationships in the agrifood system, we would help farmers, consumers and communities understand the system they were part of in order to transform it.

Our approach is different from other scholarship in economics and law that has primarily addressed concerns about agricultural consolidation by studying one aspect - horizontal integration which occurs when firms in one sector (for example pork processing) consolidate into fewer firms - at one scale, national markets (e.g. Crespi, Saitone, and Sexton 2012; Fuglie et al. 2011; MacDonald 2016). These scholars often found little reason to worry about increasing consolidation and concentration, arguing that it increased efficiency that in turn produced economic gains and that firms did not use their market power to increase prices or to discriminate against producers. 
We admit there are weaknesses in looking only at concentration in certain commodities, or employing monopoly-only models of the agrifood system. For instance, while firms may organize themselves into global production networks, those networks may still compete with each other while disadvantaging farmers and ecosystems (Hendrickson et al. 2008; Heffernan, Hendrickson, and Gronski 1999). Current concentration and monopoly models also don't address the issue of vertical integration and other structural issues in the food and agriculture value chain. To remedy these problems, some scholars have worked to differentiate between buyer and seller power, or to examine the differing levels of concentration that can harm producers, consumers or the public good in different situations (Foer 2016; Carstensen 2008; Carstensen et al. 2016). While this scholarship can lead to important insights and can result in regulatory proposals, Howard (2016a, 11), following Nitzan and Bichler, (2009), proposed a more encompassing look at capital as power - "that corporations quantify their perceived influence through 'capitalization,"' which can be viewed as a measure of their expected future earnings (in present dollars), discounted for perceived risks. This means that "[c]apitalism as a system is therefore better understood as a mode of power rather than a mode of production." Mode of production refers to the way we collectively produce what we need to survive as a society, and the social relationships that form around it. Mode of power, in contrast, does not assume capitalists are driven to increase production (nor consumption), but only their own power relative to everyone else, even if it reduces wellbeing. This approach highlights the need to understand the social, political and economic relationships that structure the agrifood system. At the core of all these works is the desire to describe and understand the power relationships that arise in an industrialized, highly capitalized agrifood system in order to address their negative impacts. 


\section{Methods}

The Missouri School method is to document economic concentration in an easily assessable format that illustrates the breadth and depth of concentration in major agricultural commodities and in different sectors of the food system (see Figure 2). We report the market shares in major agricultural commodities, agricultural inputs and food retailing in CR4 tables (CR4 is the concentration ratio [CR] of the combined market share of the top four firms in each market). We glean the data from trade journals, company annual reports, government reports, academic journals and financial newspapers. Sources used in this chapter include trade journals and newspapers such as Successful Farming, Farm Futures, European Seed, Reuters, and Fortune; government reports from USDA's Economic Research Service and Grain Inspection Packers and Stockyards Administration (GIPSA), as well as United Nations agencies such as

\begin{tabular}{|c|c|c|}
\hline $\begin{array}{l}\text { Livestock and crop } \\
\text { farmers }\end{array}$ \\
Processors \& \\
Grain Traders
\end{tabular}

Food and Agriculture Organization (FAO) and Committee on Trade and Development

(UNCTAD); non-profit research briefs where we have examined and agree with the methods 
used including from ETC Group, Food and Water Watch and Oxfam; and academic journals in law, economics, policy and sociology.

We are particularly interested in the top four firms in a specific market for two reasons. First, when four firms control more than forty percent of a market the oligopolistic/oligopsonistic structure can confer market power to those firms (Breimyer 1965; Connor et al. 1984; Heffernan 2000; Hendrickson and James 2005). Second, the theory of small group behavior indicates that actors in small groups generally inform their own actions through observation of other actors, rather than openly discussing actions with others (Olson 1965). As noted above, CR4 is a rather simplistic monopoly model, which we recognize provides an imperfect assessment of power relationships within a particular commodity (James, Hendrickson and Howard 2013). The utility of the CR4 tables is the snapshot of the dominant players in and across particular commodities that helps farmers and community members understand the wide reach of corporate actors. Because we are interested in consolidation and concentration issues across the food system, one of our major contributions is the identification of the top firms by name to document the progress of cross-commodity integration. Reading company reports, trade journals and financial newspapers also allows us to glean information about potential strategies that different actors pursue, as well as industry insights into the implications of those strategies.

\section{Results: The Structure of the Food and Farming System}

In the following pages, we attempt to provide a snapshot of different markets across the food chain (see Figure 2), which starts with the inputs farmers use to produce agricultural commodities, the commodity markets into which they sell, and the food processing and food retailing sectors that have driven a large number of changes in the marketplace in the last 25 years. We describe each link of the agrifood chain, the way markets have changed and the 
implications of those changes. But first, we want to provide a snapshot of what has happened to farmers in the last 50 years.

We have lost one-third of the farms that existed in 1964, and half of the remaining two million farms produce less than $\$ 10,000$ in annual sales (USDA 2012). Using the median size of crop acres or number of animals, MacDonald (2016) shows increasing consolidation at the farm level in the United States, where median farm size in cropland more than doubled between 1982 and 2012, and increased even more rapidly in livestock (see Table 2). Illustrating that the "Agriculture of the Middle" is declining and perhaps facing extinction, he documents that "the number of farms with milk cows or hogs fell by about $70 \%$, while those with fed cattle [steers/heifers for market] or contracts for broiler production fell by 30\%" (ibid, 5).

\begin{tabular}{|l|c|c|}
\hline \multicolumn{3}{|c|}{ Table 2: Structural Change in U.S. Livestock Production } \\
\hline \multicolumn{1}{|c|}{ Item } & 1987 & 2012 \\
\hline Midpoint farm sizes & 300,000 & 680,000 \\
\hline Broilers (annual sales/removals) & 17,532 & 38,369 \\
\hline Cattle feeding (annual sales/removals) & 1,200 & 40,000 \\
\hline Hogs (annual sales/removals) & 80 & 900 \\
\hline Milk cows (herd size) & 22,000 & 15,830 \\
\hline Number of farms with & 112,109 & 77,120 \\
\hline Contract broiler production & 243,398 & 63,246 \\
\hline Cattle feeding & 202,068 & 64,098 \\
\hline Hogs & & \\
\hline Milk cows & \\
\hline Source: MacDonald 2016 p. 5 & \\
\hline
\end{tabular}

The trends toward large-scale farms in the US (mirrored in Canada) have been on the leading edge of global shifts, suggesting what may happen to farms elsewhere that begin to industrialize with global capitalist markets. Lowder, Skoet, and Raney $(2016,27)$ show that "[f]rom 1960 to 2000, average farm size decreased in most low- and lower-middle-income countries and in South Asia as a whole. It decreased from 1960 to 1990 in Latin America and the Caribbean as a whole, before increasing from 1990 to 2000. Average farm size increased from 
1960 to 2000 in some upper-middle-income countries and in nearly all high-income countries...." Oya (2013) reminds us, however, that farm scale does not neatly define or describe the relations of production, rather we need to understand global agrifood commodity relationships, or as we conceive of it - the mode of power - that is shaping how people can participate in the food system.

\section{Concentration in the Markets for Inputs Required to Raise Crops and Livestock}

Fewer and larger farms signifies that farmers are replacing management and inputs produced on the farm with capital-intensive inputs from off the farm in many sectors of agriculture, especially in the production of pork, poultry, dairy, and row crops and within large vegetable, fruit and nursery operations. When this happens, consolidation in the input markets becomes a serious concern to the farmers who remain. In the past two decades, mergers of enormous firms have occurred in the farm machinery, fertilizer, seeds and agrichemical sectors. Of increasing concern is ownership in the digital age, including data, codes and programming upon which commercial farmers have come to rely; even smaller scale row-crop farms use GPS systems to manage soil fertility, irrigation, and especially yield data, while farmers with recently purchased tractors or combines cannot legally fix the machines themselves (Carolan 2017).

Since the late 1990s, the seed industry has consolidated rapidly both in the U.S. and globally. The introduction of Round-up Ready seeds in the mid-1990s spurred rapid consolidation among seed companies and convergence between seed and chemical companies (Howard 2009b). Essentially, a chemical company, Monsanto, became the dominant seed firm with the acquisition of more than 50 seed firms (see Table 3). Fuglie et al. (2011) estimated a concentration ratio for the top four firms (CR4) of 54 percent of global commercial seed market, with certain segments even more concentrated (for example, the global vegetable seed market 
has a CR4 of 70 percent, while in the late 2000s the CR4 for the U.S. cottonseed, corn seed, and soybean seed were all over 50 percent, see Figure 3). In the last two years, major mergers between the largest seed and chemical companies have been proposed or approved. Bayer has sought to merge with Monsanto, while the Dow-DuPont merger is nearly complete. If the mergers are approved, the new firms would control half of the global commercial seeds market (see Table 3). Lianos, Katalevsky, and Ivanov $(2016,1)$ argue that "[r]ecent merger activity in this sector ... illustrates its rapid transformation from an already concentrated industry to a tight oligopoly on a global scale."

Much of the concentration in seeds has been spurred by proprietary agricultural biotechnology that makes it illegal for farmers to save seed and also promotes tight coordination

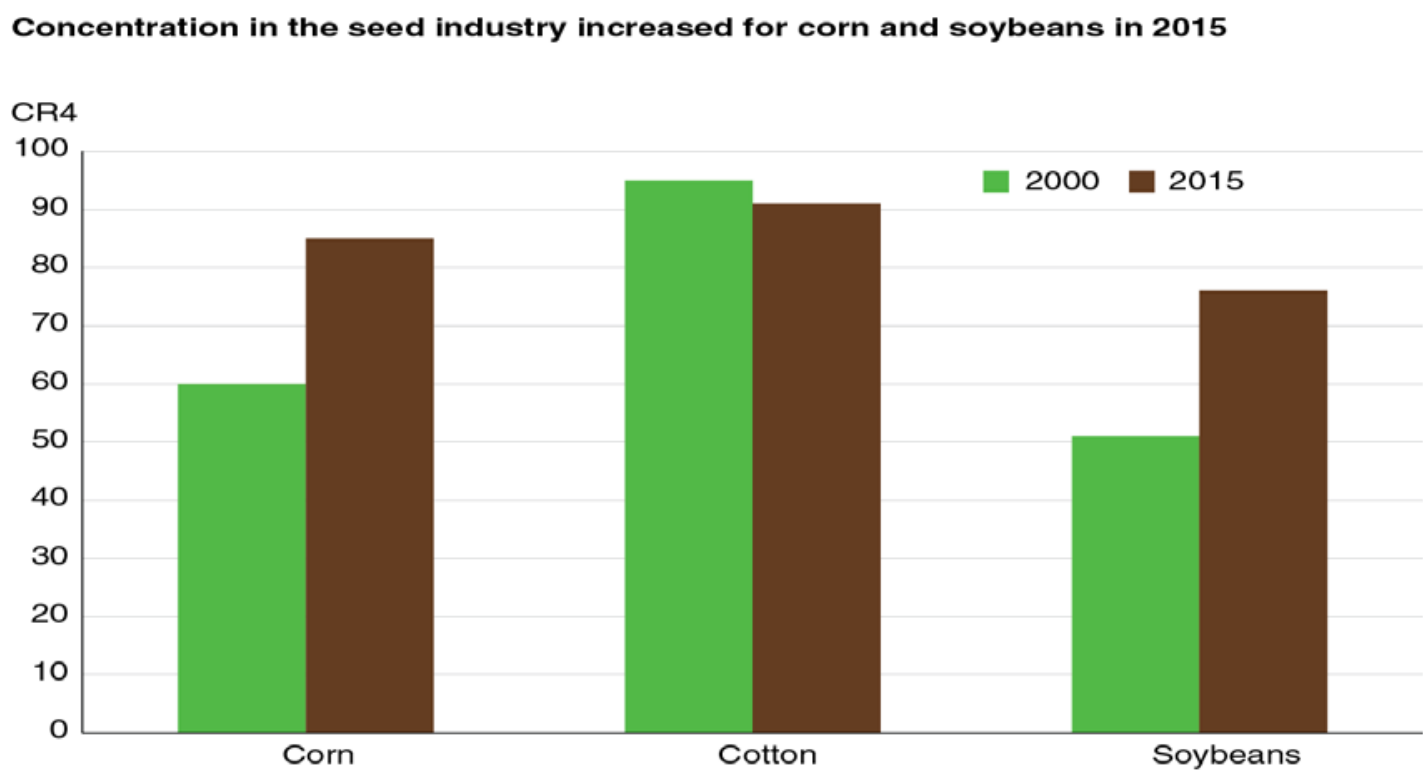

Note: CR4 is the share of sales held by the four largest sellers in the industry.

Sources: USDA, Economic Research Service using data from the USDA Agricultural Marketing Service (cotton) and the Farm Journal (corn and soybeans).

Figure 1: USDA seed market data prior to 2016 merger announcements. (MacDonald 2017)

between seed and chemical companies, especially regarding herbicide resistant traits. In the 1990s and 2000s firms that had traditionally focused on agrochemicals, like Syngenta, Monsanto and DuPont, moved into the seed industry (UNCTAD 2006). In the agrochemical sector, ETC Group (2013) notes that six global firms (Monsanto, DuPont, Syngenta, Bayer, Dow, and 
BASF) ${ }^{4}$ controlled three-quarters of all private sector plant breeding research, nearly three-fifths of the commercial seed market and over three-quarters of global agrochemical sales. ChemChina acquired Syngenta, which was the third largest global seed company and largest agrochemical company with over one-fifth of the global market in 2011 (ETC Group 2013). If the announced large mergers in the seed and agrochemical arena proceed without required divestures, three firms would sell 70 percent of agrichemicals globally based on their 2011 sales (see Table 3 which uses figures compiled by ETC Group 2013).

\begin{tabular}{|c|c|c|c|}
\hline \multicolumn{4}{|c|}{ Table 3: Global Seed \& Agrichemical Companies } \\
\hline $\begin{array}{l}\text { Seed Company \& Global } \\
\text { Rank on Global Seed Sales }\end{array}$ & $\begin{array}{l}\text { Concentration Ratio of } \\
\text { Global Proprietary Seed } \\
\text { Market (Current) }\end{array}$ & $\begin{array}{l}\text { Merger } \\
\text { Partner }\end{array}$ & $\begin{array}{l}\text { Percent of Global } \\
\text { Proprietary Seed Market } \\
\text { of Combined Firm } \\
\text { (Estimated) }\end{array}$ \\
\hline Monsanto (1) & & Bayer (7) & $29 \%$ \\
\hline DuPont (2) & & Dow (8) & $18 \%$ \\
\hline Syngenta (3) & & & $9 \%$ \\
\hline Vilmorin (4) & CR4 - 54\% & & $5 \%$ \\
\hline $\begin{array}{l}\text { WinField (5) } \\
\text { KWS (6) } \\
\text { Bayer CropScience (7) }\end{array}$ & & Monsanto (1) & \\
\hline Dow Agrosciences (8) & CR8 - 63\% & DuPont (8) & \\
\hline $\begin{array}{l}\text { Agrichemical Company \& } \\
\text { Global Rank }\end{array}$ & $\begin{array}{l}\text { Concentration Ratio of } \\
\text { Global Agrichemical } \\
\text { Market (Current) }\end{array}$ & $\begin{array}{l}\text { Merger } \\
\text { Partner }\end{array}$ & $\begin{array}{l}\text { Percent of Global } \\
\text { Agrichemical Market of } \\
\text { Combined Firm } \\
\text { (Estimated) }\end{array}$ \\
\hline Syngenta (1) & & $\begin{array}{l}\text { ChemChina } \\
\text { (7) }\end{array}$ & $29 \%$ \\
\hline Bayer CropScience (2) & & Monsanto (5) & $25 \%$ \\
\hline BASF (3) & & & $12 \%$ \\
\hline Dow Agrosciences (4) & $\mathrm{CR} 4-62 \%$ & DuPont (6) & $16 \%$ \\
\hline $\begin{array}{l}\text { Monsanto (5) } \\
\text { DuPont (6) }\end{array}$ & & Dow (4) & \\
\hline ChemChina (7) & & Syngenta (1) & \\
\hline Nufarm (8) & CR $8-87 \%$ & & \\
\hline Sources: ETC Group (2013 & Fuglie et al (2011) & & \\
\hline
\end{tabular}


No one can explain better than farmers what is happening. In 2010, a number of farmers testified at workshops on agricultural competition organized by the U.S. Departments of Justice and Agriculture. In Iowa, Todd Leak from North Dakota gave a farmer's view of the changes we documented above:

"I farm 2,000 acres with my brother in central Grand Forks County, North Dakota. I'm a soybean farmer for 30 years, and maybe about a decade ago [in 2000], I was free to choose from about a hundred different varieties of non-GMO soybeans...Today there's about 123 varieties of GMO soybeans that I have to choose from and about 12 non-GMO. Of those 12 non-GMO varieties, 6 of those are for the specialty food grade ... market ... 6 that remained to me were developed in the 1980s and 1990s and their disease packages, their host resistance are far less than the GMO varieties, and their yield is only about 70 percent of the GMO varieties, and that is not because of the GMOs. GMOs do not increase yield. There is no yield gene trait. The issue is that all of the research, all of the breeding, is going into proprietary genetically modified varieties ...I am therefore forced as a farmer to have to go to the seed companies, these few seed companies that are left, to purchase my seed." (U.S. Departments of Justice and Agriculture 2010, 126-127)

Many - but not all - farmers at the Iowa hearing agreed. Fred Bower, a Minnesota farmer and seed dealer, lamented the decrease in the number of seed companies from 50 when he started farming in the 1970s to four in 2010. He complained that he was "not being treated properly as far as price. When the amount of seed dealers goes down, the competition decreases, and they kind of run the show of what they want to say is the price. It was way better to have more seed companies involved than to have fewer seed companies at the present time and pay through the nose." (U.S. Departments of Justice and Agriculture 2010, 132) An Indiana farmer pleaded that "I need a choice of seed. I'm down to planting three varieties of public soybeans." (U.S. Departments of Justice and Agriculture 2010, 139)

As farmer Leak's testimony indicated, it is difficult to disentangle seeds, chemicals and agriculture biotechnology. Moss $(2016,11)$ reported that "[i]n 2009, the 'Big 6' biotechnology 
firms (Monsanto, DuPont-Pioneer, Syngenta, Dow, Bayer, and BASF) held greater than 95\% of trait acres for corn, soybeans, and cotton in the U.S., with Monsanto alone accounting for $90 \%$ of those acres." A recent article in Successful Farming, highlights new linkages that will arise with the proposed merger between Bayer-Monsanto:

"Monsanto is largely in the seeds and traits business, while Bayer concentrates on chemicals. ...74\% of Monsanto's 2016 sales came from seeds and traits, with the remaining $26 \%$ coming from crop protection chemicals. Bayer's flipped the other way. It derived $85 \%$ of its 2016 sales from crop protection chemicals, with just $15 \%$ coming from seeds and traits. Little overlap exists between the companies in the global seed and traits space for corn and soybeans. Monsanto's 36\% market share in corn would not change if the firms combined. In soybeans, Monsanto's current 27\% market share would rise to just 28\% if the Bayer Monsanto merger went through." (Gullickson 2017, n.p.)

Because access to genetically modified traits is so important in the current seed market, the Big 6 firms have engaged in a number of cross licensing agreements for traits that Howard (2015) convincingly argues increase consolidation in the sector and raise already high barriers to entry (for a history of how these agreements have developed see Howard 2016a). There is also the much despised patent enforcement at the farm level. A 2008 Vanity Fair article detailed Monsanto tactics aimed at enforcing patents that included videotaping and photographing farmers, and infiltrating community meetings to the point where their investigators were termed the "seed police" (Bartlett and Steele 2008, n.p.).

As we see in Table 4, livestock genetics are also highly concentrated, especially for poultry and swine production that takes place in confined animal feeding operations (CAFOs). Research on nearly all of global poultry genetics and close to two-thirds of cattle and swine genetics is controlled by four firms (ETC Group 2013;see also Gura 2007). Concentration in both seed and livestock genetics raises a number of important issues alongside the fact that farmers must now use more capital to access genetics while also having fewer choices about what kinds of seeds or breeds to use. Genetic concentration is a growing concern, especially in 
terms of disappearing livestock breeds (FAO 2015), which means animals may be more susceptible to evolving pathogens (Howard 2016a) or could also be less resilient in the face of climate change (Hendrickson 2015).

\begin{tabular}{|l|l|l|l|}
\hline \multicolumn{2}{|l|}{ Table 4: Concentration in Livestock Genetics } & \multicolumn{2}{l|}{ Swine } \\
\hline Turkeys & Laying hens & Broilers & Genus \\
\hline EW Group & EW Group & EW Group & Hendrix Genetics \\
\hline Hendrix Genetics & Hendrix Genetics & Tyson & Groupe Grimaud \\
\hline & & Groupe Grimaud & Smithfield/WH Group \\
\hline & & & $\begin{array}{l}\text { Four firms control 2/3 of } \\
\text { research \& development }\end{array}$ \\
\hline CR2 99\% & CR2 94\% & CR3 95\% & \\
\hline Source: Adapted from Howard (2016a) based on data from ETC Group (2013).
\end{tabular}

While improved genetics in seeds and breeds certainly increased agricultural productivity (yield), about half the gains made in the $20^{\text {th }}$ century owes to inorganic fertilizers, particularly for critical crop nutrients such as nitrogen $(\mathrm{N})$, phosphorous $(\mathrm{P})$ and potassium $(\mathrm{K})$, also commonly referred to as potash (Aziz et al. 2015). Maintaining and enhancing soil fertility has been one of the key struggles of human civilization; Montgomery (2012) argues that many great civilizations have collapsed due to the exhaustion of soils. Europe's vigorous imperialistic search for external sources of N was solved by the development of synthetic N (Foster and Magdoff 2000), while industrial mining techniques facilitated trade in $\mathrm{P}$ and $\mathrm{K}$. These $20^{\text {th }}$ century developments led to the capital-intensive fertilizer industry that has long been controlled by sprawling transnational firms, or even cartels of large vertically integrated firms, with substantial support from national governments. Global fertilizer companies such as Yara, Potash Corp, Agrium, Mosaic, OCP (Morocco) and a Russia-based potash cabal dominate the market (Taylor and Moss 2013). In 2016, Potash Corp and Agrium announced merger plans to create the largest fertilizer company in the world. Taylor and Moss (2013) argue that global fertilizer producers have been able to act 
"in a coordinated fashion" on price, but that buyer power on the part of markets in places like India and China have potentially curtailed those actions. The U.S. and Canada have legally sanctioned export cartels in fertilizers, primarily in the phosphorus industry, where Taylor and Moss (2013) identify a duopoly, Potash Corp and Mosaic called PhosChem, that controls 52 percent of the world's phosphorus (P) trade. PotashCorp, Agrium and Mosaic also cooperated in a legally sanctioned export cartel, Canpotex, which accounted for 61 percent of the world potash trade.

Farmers have also seen the farm machinery sector consolidate rapidly in the past two to three decades, in North America and globally, with a few large firms dominating machinery markets across the world. As discussed above, mechanization has spurred specialization and centralization in U.S. agriculture, resulting in high capital costs for farmers raising commodity crops or livestock. John Deere is the largest domestic and global agricultural machinery firm, followed by CNH Industrial (a merger of Fiat and CNH Global) and AGCO, which includes many iconic brands such as Massey-Ferguson, Gleaner and White. In 2011, 10 global firms had sales greater than $\$ 1$ billion, accounting for over one-third of the global market. In just 15 years between 1994 and 2009, the four largest machinery manufactures increased their market share from 28 to 50 percent of global sales (Fuglie et al. 2011).

Concerns about consolidation in the agricultural machinery market arise in two different arenas. One regards digital information in terms of who captures it, who uses it and who owns it. Precision agriculture, developed with the aid of GPS systems, has been an important tool for farmers to monitor their soil fertility, crop yields and input use. Nearly three-quarters of U.S. corn acres employ precision agriculture practices (Carolan 2017). Arguably precision agriculture has significant ecological benefits, particularly in the reduction of fertilizer and pesticide use - 
up to 30-40 percent according to some analysts (Burger 2016). Such reductions in input factors potentially jeopardize the business models that the Big 6 seed/chemical firms rely on, hence their interest in acquiring farm management software and digital companies. Farmers worry because precision agriculture relies on the transmission of substantial amounts of data from tractors, harvesters, sprayers in crop production, and from electronic tags, feeding equipment and milking equipment in livestock production. Farmers have concerns about the ownership of this data, as well as the value of such large amounts of data to powerful market actors. Brian Marshall, a member of the American Farm Bureau Federation, testified before the U.S. Congress that "[v]irtually every company says it will never share, sell or use the data in a market-distorting way - but we would rather verify than trust" (Plume 2014, n.p.). Plume also writes that large companies are trying to figure out how to position themselves for the future, when more farmers will participate in data sharing. Monsanto's ownership of Climate Corporation, which specializes in collecting and analyzing soil and weather data to allow farmers to make "datadriven" decisions, was considered a key enticement for Bayer's offer to buy Monsanto, as Bayer has lagged behind in developing data platforms. ${ }^{5}$ As Monsanto's CEO, Hugh Grant, says, "The company of the future won't just be selling seeds and chemicals, but seeds and chemicals and data as a service" (Murray 2016, n.p.).

A second concern regards innovation, which has long been a source of pride for farmers who adapted their machinery to improve its fit with their needs. One only needs to read magazines like Farm Show or Successful Farming to find multiple examples of farmers "hacking" machinery and sharing their insights with other farmers. In a rare case, the U.S. Department of Justice blocked a proposed merger of Deere and Precision Planting (Monsanto) because the merger would hamper farmer innovation in retrofitting their planting toolbars. Still 
the top two precision planter manufacturers control over 80 percent of the high-speed precision planting equipment market (U.S. Department of Justice, 2016). Some analysts speculate that as combined seed/chemical firms struggle to increase power faster than other firms, they will be vulnerable to takeover by machinery firms. Thus, we could potentially see greater levels of bundling of input packages, comparable to when chemical firms took over the seed industry. As long-time agricultural concentration observer Pat Mooney $(2017,4)$ writes, "At least since the new millennium, the dominant farm machinery companies have invested heavily in satellite and sensor information and Big Data management. With this data, the machinery companies stand to know more about the inputs and outcomes of every field than any other company and even the farmer. Machinery companies have the "box" in which the other input companies have to put their seeds, pesticides and fertilizers."

\section{Beyond the Farm Gate: Where Can Farmers Sell their Products?}

While farmers are facing decreased choice in which inputs to use, they also face just a few processors or grain traders through which to market their agricultural products. Globally, Archer Daniels Midland (ADM), Bunge, Cargill and Louis Dreyfus are often referred to as the ABCDs of the global grain trade because of their dominant position in moving grain between nations (Murphy, Burch, and Clapp 2012; Howard 2016a). In the U.S. grain sector four or fewer firms control nearly all of cane sugar processing, over four-fifths of the wet corn milling, beet sugar processing, and soybean crushing markets (Adjemian et al. 2016). For flour milling, just one joint venture, Ardent Mills (co-owned by Cargill, ConAgra and CHS), controls approximately one-third of the market, leaving farmers in some parts of the country few options to sell their wheat (Howard 2016b). 
The same situation exists in the livestock sector as demonstrated in Table 5. Farmers rely on the same dominant firms across the entire protein (chicken, pork and beef) sector, including Tyson Foods, JBS, and Smithfield (held by WH Group from China). While we report primarily U.S. data, the rise of just a few firms dominating the protein sector is a global phenomenon.

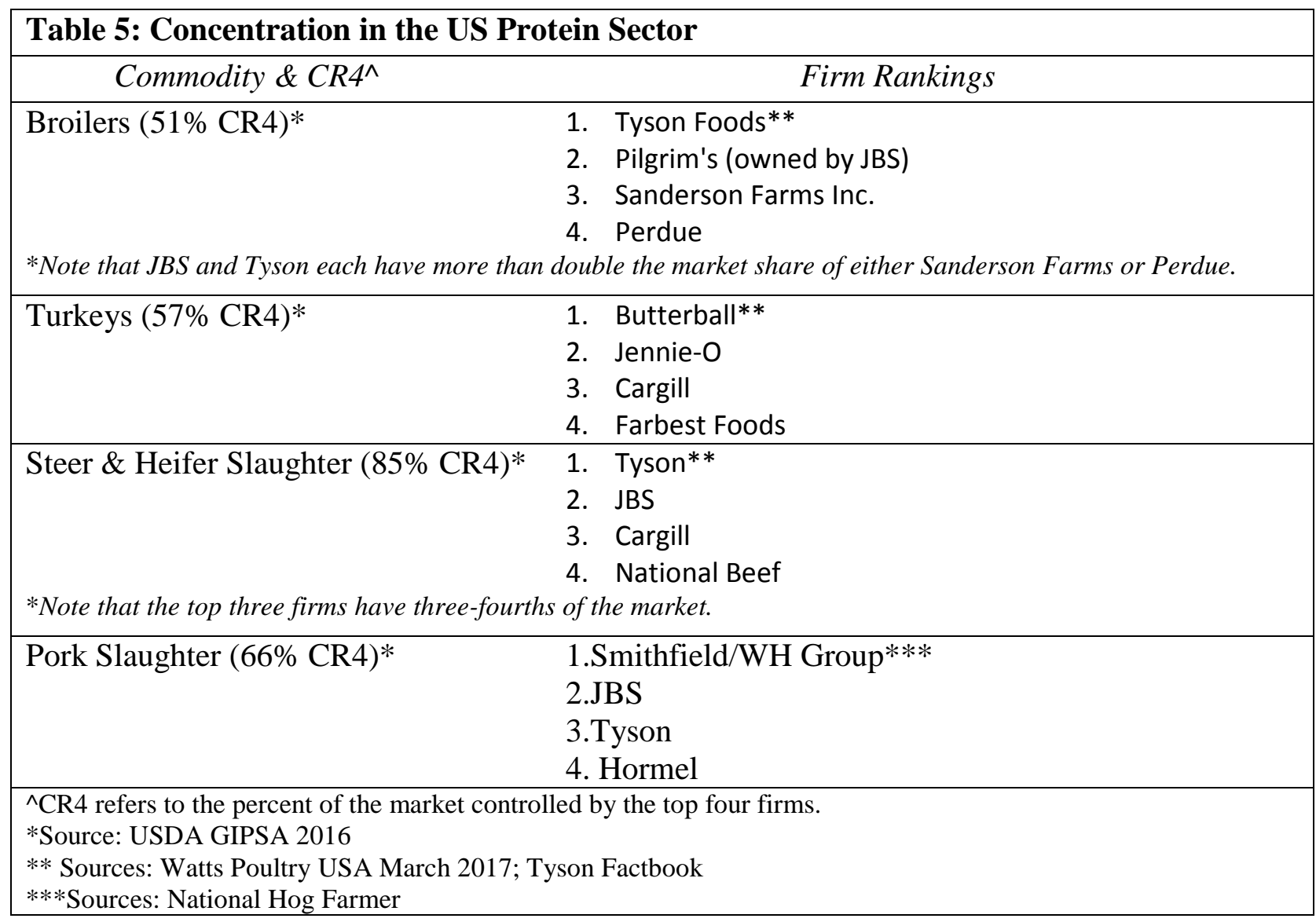

Take the case of Tyson Foods. After rising to dominance as the largest poultry company in the United States through aggressive mergers and acquisitions during the 1980s, Tyson began to diffuse this “Southern Model” (Constance 2008) of poultry production into Mexico in 1988 through a joint venture with Mexican and Japanese companies. By 2003 it was the second largest poultry firm in Mexico. During this same time, the company acquired, or developed joint ventures with, numerous companies around the world, most importantly obtaining Iowa Beef 
Packers (IBP) in 2001, which allowed it to become the largest meat packer in the world with major holdings in beef and pork added to its poultry (broilers and turkey) portfolio. Tyson perfected its global expansion model in Mexico and during the late 2000s, expanded aggressively into the emerging markets in Brazil, India, China and other countries globally (Constance et al. 2010).

Brazil's JBS followed Tyson's model with several acquisitions starting in the early 2000s to become the largest meat company and beef packer in the world. These purchases included, among several others, the assets of Swift Foods (beef) in the U.S., Australia, and Latin America; Cargill's pork operations in the U.S.; and Pilgrim's Pride (poultry) in the U.S. and Mexico. JBS benefitted from substantial investments from Brazilian government-owned banks, but was forced to sell some operations in summer 2017 after admitting to corruption in Brazil (Howard 2017). Interestingly, this government support gave JBS an advantage over Tyson in Latin America, and as a result, Tyson sold its Mexico and Brazil divisions to JBS in 2014.

Smithfield, facing credit issues after the financial crisis in 2007-2008, was acquired by WH Group, a Chinese firm that has significant ties to the Chinese government (Howard 2017). WH/Smithfield is the world's largest pork producer, with 1.1 million sows in production worldwide, including holdings in the U.S., Mexico, Poland and Romania, ${ }^{6}$ and it is rapidly expanding its poultry operations in China. WH Group has announced its intention to acquire more international competitors, with the goal of becoming the world's largest packaged meat firm (Sito 2016). At the time of this writing, WH Group is seeking to acquire beef and poultry assets in Europe and North America, partially because these regions' cheap grain and strong demand for meat increase profitability (Polansek and Zhu 2017). Howard (2017) argues that these global meatpackers, notably WH Group, JBS and Tyson Foods, have increased 
significantly in size over the last decade, partly due to government subsidies, especially in the first two cases. Their global scope also allows these firms to circumvent national regulations, such as import bans or higher tax rates, via the use of subsidiaries in other countries (Degan and Wong 2012).

Consolidation in the livestock sector has been accompanied by increased use of contracts and forward contracting, ${ }^{7}$ with a transparently negotiated cash market all but disappearing. According to USDA's GIPSA (2016), nearly three-fifths of the steers and heifers slaughtered for our dinner plates were procured using a formula pricing system that references an exogenous price (either based on a dwindling cash market or cattle futures), with only 30 percent of total steers and heifers procured moving through the cash market, which is half what it was in 2007. In the past, cash markets have been valued by farmers as they were established in places where several buyers might bid on a single group of cattle or hogs and the farmer had the choice of whether or not to accept that price. Today cash markets are residual markets. To illustrate, an Iowa farmer, Eric Nelson, had this to say in the 2010 workshops: "The fewer competitors, particularly in my cattle operation, it's not unusual in a week's time that we're down to 15 and 20 minutes cash market per week compared to a grain producer maybe has 1,500 minutes a week in order to make grain sales, and it's because there are only a handful of end users in the cattle market" (U.S. Departments of Justice and Agriculture 2010, 62).

The situation is worse in pork production, where only two percent of hogs are marketed through negotiated cash markets, with the remainder of hog production procured through formula pricing and marketing agreements (GIPSA 2016). The latter two forms often relied on the cash market as the basis for their own formulas for paying producers. The disappearance of the cash market indicates the hog sector has moved into very similar marketing arrangements as 
have existed in broilers, eggs and turkeys for several decades (Breimyer 1965). These arrangements do not use a transparent marketplace to negotiate the actual price per pound or animal; instead, broiler integrators use a complicated and purposefully opaque formula to pay their growers. Thirty-five large hog producers now own two-thirds of U.S. sows, with the top four firms owning 1.74 million sows or about 30 percent of the total. ${ }^{8}$ Economists sometimes refer to these as "thin" markets, or markets where there are "few purchasers, low trading volume and low liquidity" (Adjemian. et al. 2016, 2). Adjemian et al. (2016) argue that small producers are often left out in thinning markets because of the costs of using contracts, as well as the economies of scale that favor larger producers, even though they find no impact on prices received by producers in thinning markets. The structure of these end markets is reflected in what's happened on farms (see Table 2), where less than 10 percent of farms with hogs and pigs produced 50 percent of all hogs and pigs sales, with similar numbers for dairy and poultry (Adjemian et al. 2016). While farmers may not have the data scholars do, they know the problems. During hearings on competition in agriculture, farmers "charged that the thinning of spot markets reduces market transparency, denies producers opportunities, reduces their bargaining power, and yields prices not accurately reflecting underlying supply and demand” (U.S. Department of Justice 2012, 12).

\section{Retailers Drive Changes}

Consolidation in commodity processing has been matched by increasing concentration in food retailing, where food retailers have been accused by farmers and workers of exerting market power to force lower prices back through the system to the farm gate (U.S. Department of Justice 2012). In the decade after Wal-Mart started selling groceries in the late 1980s, traditional grocers like Kroger acquired regional firms to become truly national, coast to coast retailers 
(Howard 2016a;Hendrickson et al. 2001). Today, the top four food retailers sell Americans over 60 percent of their groceries. ${ }^{9}$ Through the 1990s, traditional grocery retailers like Kroger or Safeway dominated the particular metro markets in which they operated, but Wal-Mart's entry into food retailing prompted national and international mergers (Howard 2016a). Wal-Mart also brought a different business model to groceries, focusing on supply chain efficiencies and negotiating with suppliers for the lowest price. As the firm gained power in the grocery market, they exerted pressure on suppliers, which in turn motivated mergers among suppliers. For example, Tyson acquired IBP to supply the whole protein case (everything from chicken legs to pork chops to hamburger) to Wal-Mart (Hendrickson et al. 2001). Many food manufacturers, especially in the packaged food space, might derive at least 20 percent of their net sales from Wal-Mart stores. ${ }^{10}$ Food and Water Watch $(2013,2)$ summed up the grocery landscape this way: "The top companies controlled an average of 63.3 percent of the sales of 100 types of groceries....In 32 of the grocery categories, four or fewer companies controlled at least 75 percent of the sales. In six categories, the top companies had more than 90 percent of the sales, including baby formula and microwave dinners.... Retailers exert leverage by picking and choosing their suppliers, but suppliers rely on a few retailers for the bulk of their sales." In the summer of 2017, a new disruption in food retail emerged with Amazon's acquisition of Whole Foods. Kowitt (2017) suggests that the $\$ 800$ billion grocery business and its suppliers may be in for a new round of cost-cutting reminiscent of what happened to publishers and bookstores as Amazon built its book business. The new parent firm immediately dropped Whole Foods prices on organic rotisserie chicken, bananas, apples and avocados by approximately 30 percent, for example. Cost cutting in the food industry has often (if not exclusively) been borne by farmers, workers and small businesses. 
Finally, we should mention that the last decade has seen large changes in the locations of where Americans actually nourish themselves. USDA's Economic Research Service reports that by 2013, the percentage of dollars spent on food away from home matched those spent for food to be consumed at home. ${ }^{11}$ Concentration in the restaurant and food service market can also be a concern for farmers and other suppliers. Howard (2016a) reports that four firms have over 40 percent of the fast food market (McDonald's, Yum! Brands, Doctor's Associates, Inc. [Subway], and Wendy's). Two distributors, Sysco and U.S. Foods dominate food distribution to food services such as restaurants, hospitals and hotels/hospitality concerns. ${ }^{12}$ One firm, 7-Eleven, has nearly one-quarter of the U.S. convenience store market (Howard 2016a). For farmers, the consolidation in food distribution, retailing and restaurants means there are fewer players for the firms which buy farm gate products to sell to - essentially the very firms who have power over farmers find themselves in a less powerful position vis-à-vis food distributors or grocers. Why does this matter? Market power exercised at the retail level extracts concessions from the food processor, which in turn extracts concessions from the farmer who has no one (outside of the farm ecology or farmworkers) to extract concessions from. More practically, farmers providing alternative produce, meat, or dairy items can find themselves in a catch-22; too small to supply a firm like U.S. Foods even when customers would like to order from them yet too large to direct market.

In summary, the industrialization and consolidation of agriculture has meant that farmers specialize in certain crops or in single animal production; specialization has meant significant capitalization. Markets for seeds, fertilizers, pesticides and farm machinery have consolidated both in North America and globally in the last two decades constraining the choices farmers have of which seed varieties, animal genetics, soil fertility practices or pest and weed management 
strategies to use. Knowledge and information in managing farms (i.e. precision agriculture or genetically-modified seeds) has also commodified during this time, becoming a significant source of power for transnational firms. Farmers face limited choice of where to sell their products as major commodity markets, especially in grains and livestock, are consolidated. Finally, large grocers exert power over suppliers in consolidated food retail market.

\section{Discussion: Resisting and Reshaping the Agrifood System}

While it may seem the structural conditions in the agrifood industry that we have described are insurmountable, in reality they are created and shaped by human actors. The "Emancipatory Question" then becomes "what kind of agrifood system might decrease injustice and inequality" and how do we achieve it (Constance 2009, 9)? In this section, we showcase how farmers in North America and across the globe, along with workers and consumers, have fought back against the changes we described above, to stop them, to shape them or to go around them.

First the bad news; resistance to this highly coordinated, capitalized and industrialized agrifood system has been fragmented and less than successful at stopping the larger trends (Constance et al. 2014a). After four decades of anti-trust reinterpretation to a singular focus on efficiency and price (Howard 2016a), farmers joined with allies in pressing the Obama Administration for movement on anti-trust issues, resulting in a series of workshops exploring competition in agriculture and food markets in $2010 .{ }^{13}$ What began as a bang, ended with a whimper when the final report issued by the U.S. Departments of Justice and Agriculture claimed that "anticompetitive mergers and discussions represented only a portion of the concerns voiced at the workshops" and that claims about "fairness, safety, promotion of foreign trade, and environmental welfare" were outside the purview of anti-trust law (U.S. Department of Justice 
2012, 3). In another form of grassroots resistance, organic production and distribution systems grew out of environmental concerns about overuse of synthetic chemicals, health concerns about what those chemicals did to human bodies, and social concerns about small-scale farmers. Today, however, the organic challenge has become "standardized resistance" (Howard 2009a, 2016a) with coopted certification schemes that have shoehorned a broad movement with multiple goals into a narrowly defined set of production practices (Jaffee and Howard 2010; Guthman 2008). Other farmers and consumers have turned to community or local food systems as a way to subvert the consolidated food system. Mount (2012) and DeLind (2011) worry that these projects, founded on authentic relationships and democratic participation are being stripped of their potential for radical transformation as they scale up to find efficiencies and lose sight of original goals. Indeed this is exactly what scholars would expect in a system embedded in the "mode of power" we described.

Still, as Howard (2016a) argues, there have been some small successes, particularly in the areas of removing objectionable ingredients (such as extruded beef, also known as "pink slime" or rBGH in milk), improving animal welfare practices through both market (for example, movements toward cage-free poultry in the U.S.) and government regulation (such as banning the use of gestation crates for sows in the European Union), and marginally improving wages through consumer campaigns (e.g., Coalition of Immokalee Workers). It would be tempting to stop here, acknowledging that the existing mode of power is very difficult to transform. However, our commitment to the possibilities of transformation requires us to examine patient, long-term struggles. In fact, following Nitzan and Bichler (2012), it may be that the allencompassing mode of power we have described in this chapter is approaching the limits to what society will accept (e.g. the seed industry is having difficulty increasing prices to farmers, 
declining beer sales are forcing the two global brewers to look to non-alcoholic beverages for growth). While Nitzan and Bichler are optimistic that at some point resistance will overcome (agrifood) capitals' ability to continue to concentrate and the latter's power will disintegrate, this hope remains an empirical question that has not yet been answered.

Restoring Fairness and Competition in the American Agrifood System Against all odds, farmers continue authentic calls for justice through democratic institutions such as the courts and government policy. In 1996, a group of cattlemen filed suit against then IBP (later Tyson) alleging that the firm was large enough to control prices, claiming that the firm artificially depressed prices by around five percent, thereby giving the company one free out of every 20 cattle purchased (Harris 2004). The suit, filed under the Packers and Stockyards Act of 1921, was given class status in 2001, and proceeded to trial in 2004 (Taylor 2007). The jury awarded a $\$ 1.3$ billion verdict, even though Taylor (2007) argues the plaintiffs generally were seeking injunctive relief to stop the practice rather than monetary damages. The judge in the case almost immediately overturned the ruling, and the U.S. Supreme Court refused to hear the cattlemen's appeal. At the 2009 Organization for Competitive Markets annual meeting, the lead plaintiffs' attorney, David Domina, urged the audience to stay engaged and to fight for new competition policies at the Congressional level because the judicial system had shown it was unsympathetic to these claims. ${ }^{14}$ While this is a depressing story that starkly underscores the weak position of producers under the current mode of power in agrifood, it is also significant that a jury - which had access to the actual financial details presented at trial found for the plaintiffs, legitimizing their complaint. Moreover, antitrust scholars have redoubled their efforts to examine buyer power issues, and some expressed concern that the judge muddled the statues and thus the legal proceedings when overturning the jury judgement 
(Taylor 2007). The case also helped to lay the groundwork for establishing rules to define the ninety-year-old Packers and Stockyards Act (PSA), resulting in new provisions to amend the act in the 2008 Farm Bill. After a long fight, a new rule went into effect in 2012 (Greene 2016). Despite having won in both Congress (with new directions to interpret the PSA in the Farm Bill) and the Obama Administration (new rules were promulgated and enacted), activist farm organizations lost the battle because Congress refused to appropriate money for USDA's GIPSA to enforce the PSA.

These so-called "GIPSA rules" were also influenced by the work of farmers and their allies in the early 2000s, when sixteen state attorneys-general drafted a model "Producer Protection Act," some of which was adopted in individual states (Peck, 2006; Wu and MacDonald 2015). Along with the beef producers mentioned above, contract poultry growers have fought long and hard to get new rules for contract growers into federal policy. In December 2016, USDA announced a set of "Farmer Fair Practices Rules" which were declared to target the most harmful practices aimed at poultry growers, and to restore fairness within the PSA by defining unfair practices and undue preferences. ${ }^{15}$ While broadly supported by organizations such as the National Farmers Union, Organization for Competitive Markets, contract poultry growers associations, and even the American Farm Bureau, the rules are unpopular with organizations with mixed memberships of industry and farmers and ranchers, such as the National Pork Producers Association and the National Cattlemen's Beef Association (Farm Futures 2017). The rules were withdrawn by the Trump Administration in 2017.

While not the victory farmers were looking for, these fights demonstrate that continued resistance can be important in shaping the playing field, building new alliances with consumers, and planting seeds for the future. In recent years, media attention shined light on the plight of 
contract growers through sharp comedy on John Oliver's Last Week Tonight in 2016 and Chris Leonard's 2014 expose of the poultry industry in The Meat Racket. On another front, economists like Wu and MacDonald $(2015,5)$ acknowledge that tradeoffs between efficiency, the need to reduce unnecessary costs of production, transportation or regulation in order to achieve more economic gains, and distribution, which is dividing the gains fairly, may need to be addressed, potentially by separating regulations derived from antitrust law from those derived from tort law. Using the latter to address concerns around competition could "facilitate regulatory oversight of policies that enhance transparency, protect property rights, and prohibit misinformation and fraud." This could prove a promising avenue to address market power as one argument in economics revolves around the idea that codification of protections for producers, workers, consumers or the environment decreases efficiency and thus creates a smaller economic pie to divide up. Wu and MacDonald (2015) suggest government enforcement of property rights or protections against fraud or misinformation actually facilitate efficiency, thereby implying that protections for farmers from exploitation of market power could offer wide benefits.

\section{Building new linkages in the food system}

Many of those fighting for better terms for contract growers and advocating for anti-trust enforcement and reform are simultaneously working to create new linkages in the food system. In North Carolina, RAFI-USA has helped farmers fight discriminatory lending practices, predatory contracts, and financial distress while also providing support for farmers to try alternative markets and production practices. In the 1980s, for example, Tom Trantham was resigned to selling his beloved high-producing dairy cows before he worked with RAFI to implement a sustainable grazing plan that reduced his costs and allowed him to access new markets for on-farm bottled milk. ${ }^{16}$ In Missouri, farmers working through the Missouri Rural 
Crisis Center waged battles against farm foreclosures caused by the 1980s Farm Crisis, fought the "chickenization" of the hog industry through a pork check-off vote, and also founded a producer cooperative, Patchwork Pork, to market naturally raised pork from members' farms. In Kansas, Organization for Competitive Markets co-founder Mike Callicrate was an original member of the Pickett vs Tyson lawsuit but went on to develop Ranch Foods Direct, a company that includes cattle finishing, a mobile meat processing unit, a Colorado Springs retail outlet, and a processing/slaughter facility. ${ }^{17}$ Elizabeth Henderson of Peaceworks Organic Farm in New York raises organic foods and distributes through a community-supported agriculture farm, but also co-founded the Domestic Fair Trade Association and advocates for fair markets. In Wisconsin, the Farmers Union created a food hub cooperative to market members' products to local stores, restaurants and schools. ${ }^{18}$ To push back against the centralization and commodification of knowledge in farm machinery, farmers organized themselves into Farm Hack, a global community of innovative farmers building and modifying farm implements - and then sharing their "hacks" with others (Carolan 2017). We include these examples to show how farmers embedded within the highly industrialized, capital-intensive systems struggle both to reshape commodity markets while also seeking to create alternatives that can transform food system relationships.

\section{Ongoing farmer/peasant struggles}

The concentration and industrialization of the agrifood system is not just a U.S. or Canadian experience. Instead, smallholders around the world face many of the same constrained choices as North American farmers, with far fewer resource (Hendrickson et al. 2008). Olivier de Schutter, former United Nations rapporteur on the right-to-food, has called for agroecological farming practices that would reduce the dependence of small-scale farmers on capital intensive 
inputs and create local and regional food markets (de Schutter 2010a). De Schutter went on to found the International Panel of Experts on Sustainable Food Systems that uses evidence-based research to inform policy debates on food systems around the world. In 2016 and 2017, this group released three monographs dealing with concentrated agrifood systems and impacts on health and ecology. ${ }^{19}$ However, the most widespread and potentially transformative movement is that oriented to food sovereignty, which seeks to move decisions over food - from production to consumption, from seeds to land, from market access to food safety - from the corporate realm into the hands of farmers and eaters around the world.

Desmarais $(2017,3)$ says that "food sovereignty is best understood as a radical democratic project that, on the one hand, exposes the power dynamics within the current global food system, and on the other hand, cultivates new spaces (at all levels) for inclusive debate on a whole set of different issues related to food, agriculture and provisioning." Originating in the myriad peasant and farmer groups that together make up La Via Campesina ${ }^{20}$, food sovereignty was the rejection of the dominant food security discourse that sought to maximize food production and enhance food access, all through a corporate neoliberal regime that focused on markets as a solution (Wittmann, Desmarais, and Wiebe 2010). The definition of food sovereignty remains fluid, despite the best efforts of academics. A Zimbabwean farmer, Elizabeth Mpofu, chastises those who don't understand that the movement is simultaneously within, against and beyond our current mode of power (neoliberal capitalism).

"We are not trying to create the perfect definition, for a dictionary or for a history book. We are trying to build a movement to change the food system and the world. To build a powerful movement, you need to add more allies. And as you add more allies, you have more voices. More contributions. More issues to take into account. So your concept grows, it evolves, it broadens. To understand what Food Sovereignty is for La Via Campesina, yes, it is a vision of the food system we are fighting for, but, above all, it is a banner of struggle, and ever evolving banner of struggle." ${ }^{21}$ 
Wittmann, Desmarais, and Wiebe (2010 p 4) point to the power of food sovereignty as forcing us "to rethink our relationships with food, agriculture and the environment. But, perhaps the most revolutionary aspect ...is that it forces us to rethink our relationships with one another." What this means in reality is that a farmer on an industrialized wheat farm in Saskatchewan, a member of the National Farmers Union of Canada, can find purpose and solidarity with a peasant farmer from Zimbabwe or an American corn producer on issues of agriculture and food trade and agroecological production. The meeting and sharing of these disparate interests provide an alternative view of the potential for transformation of the food system. As Desmarais (2017) says, food sovereignty is ultimately about the return to creating community, prioritizing relationships as best we can above the market.

\section{Conclusion: Contested Agrifood Transitions}

In this chapter we have sought to describe the current mode of power - the drive of agrifood firms to increase their own power relative to everyone else, even if it reduces wellbeing

- that is at work in the global food system. We have detailed the consolidated and concentrated markets that farmers face from buying inputs to selling their products, situations that exist across the globe from the U.S. to China. Farmers face constrained choices for everything from seeds and livestock genetics, to fertilizers and chemicals, to commodity processing. Global behemoths, many with assistance from national governments, have come to dominate markets for seeds, pesticides, fertilizers, genetics, livestock and grain processing, food manufacturing, food retail and fast food. Markets have globalized with decisions about what food to produce, where and how to produce it, who will produce it, and who will eat the resulting products centralized in the hands of a few decision-makers located in global production networks. Such 
constrained choices make it difficult for farmers to use practices that protect their ecosystems, that treat workers well, that strengthen their communities and that provide for economic development in their region. They also make it difficult for everyone else to support these farmers in making their preferred choices, and steer us toward locking in existing power relations.

However, as the number of agrifood firms decreases, and the negative impacts of capitalists' power become more visible, new linkages between farmers and eaters, farmers of the North and farmers of the South, environmental groups, labor activists, small food businesses, animal welfare advocates and others are emerging. Perhaps the best way to encapsulate the ongoing resistance to a globalized, industrialized agriculture is to examine proposed solutions to the looming problem of making sure that all of the nine billion people expected to be on earth by the mid- $21^{\text {st }}$ century will have enough of the right kind of food to eat, especially as we scrape the bottom of the barrel of "stored, concentrated energy -- fossil fuels, rock phosphate, potash, fossil water" and face higher energy and input costs, less freshwater and good soil, and increased adverse weather events (Kirschemann 2015). Two competing visions of agriculture have emerged as the path forward towards addressing this challenge: (1) food security through sustainable intensification, and (2) food sovereignty through agro-ecology (Constance et al. 2014b; Levidow 2015).

The food security discourse began in the 1940s when the United Nations Food and Agricultural Organization (FAO) was created to establish global food security. Although the FAO embraced the scientific extensification and intensification of world agriculture to boost production, it also included the Universal Declaration of Human Rights, which maintained that food was an essential right of life rather than a commodity. The Cold War subverted FAO 
multilateralism as the United States employed bilateral food aid to counter the spread of communism. The FAO vision of food as a right was replaced in 1986 when the World Bank redefined food security as the ability to buy food. In 1994 the World Trade Organization (WTO) institutionalized this market vision of food security whereby countries grow and trade agrifood products based on comparative advantage and people buy these foods instead of grow them. The WTO’s Agreement on Agriculture in 2008 furthered this vision by defining the new agriculture as system of global entrepreneurial farmers employing sustainable intensification practices linked to agrifood transnational corporations in flexible arrangements governed by sustainability standards (Ingram et al. 2010; McMichael 2009).

As noted in the above section, the food sovereignty movement posits a counter frame to food security approaches. Represented by La Via Campesina, this view challenges and denies the validity of the WTO-sanctioned food security framework based on free trade and corporate rights. Instead, La Via Campesina builds coalitions to create agrifood self-sufficiency through land reform, indigenous knowledge, and the regionalization of agrifood systems based on agroecological principles (Desmarais et al. 2014; Fairbairn 2012; Rosset and Martinez-Torrez 2014; Wittman et al. 2010). These include the assumption that moderate and smaller scale agroecological farming, situated and adapted in a particular place, is more resilient to climate shocks than industrial agriculture as well as the idea that domestic agrifood production is the better path to agrifood sustainability than global commodity chains (de Schutter 2010b).

At their heart, these two contrasting perspectives represent alternative conceptions of modernity (Desmarias 2007; McMichael 2014). The food security discourse separates the social and physical sciences and casts traditional agriculturalists as primitive laggards whereas the food sovereignty frame values interdisciplinary approaches, honors indigenous knowledge, and 
pursues social justice, which is the crucial fault line in agrifood studies (Allen 2008; RiveraFerre 2012). Food security proceeds from a land commodification perspective, which assumes the problem of food supply can be solved through a high-tech repackaging of the adoption and diffusion approaches of the productivist paradigm that has underlined the global consolidation of the agrifood system we described in our results. In contrast, food sovereignty views land through a multifunctional lens, employing a full-cost accounting approach that internalizes the unsustainable externalities. It embraces a rights-based rather than market-centered framework where rights are defined in collective rather than individual terms (McMichael 2014). The food sovereignty perspective proposes a repossession of the land in the face of the continuing enclosures based on accumulation through dispossession. The intellectual property rights/copy right framework advanced by the WTO is countered by a copy-left and open-source framework advanced by La Via Campesina. The battle between La Via Campesina and the GMO seed TNCs over seed sovereignty is a crucial example of the conflicting paradigms (Kloppenburg 2010).

The tension between the food security and the food sovereignty visions aligns directly with the two proposed transition paths to a sustainable global agrifood system. The food security path is based on neo-productivist solutions that have resulted in the concentrated agrifood system we described, diffused globally from Europe and North America around the world, as the new paradigm to meet the challenge of feeding the world with sustainable intensification (Almas and Campbell 2012; Levidow 2015; Marsden 2013). The food sovereignty path is based on agroecology and a social justice framework. The food security path is patterned on utilitarian assumptions about agrifood science and rurality. The greater good for the most people outweighs the negative impacts on the few. The agroecology path employs rights-based rhetoric grounded in a social justice agenda (Thompson 2010). The food security path includes incremental, green 
reforms to the existing system, while the food sovereignty path pushes for transformative change to the system (Constance et al. 2014b; Holt-Gimenez and Shattuck 2011). With little evidence, the neo-productivists promise their hi-tech green solution can feed the world, while the low-tech agroecology approach cannot. The agroecologists warn that sustainable intensification is an oxymoron at least, and more probably a 'wolf in sheep’s clothing.'

In the end, it is likely that the industrialized agrifood system - even dressed up through sustainable intensification - will have to change if we want to continue to feed human society in ways that acknowledge our indisputable connection with, and impact on, Earth's ecosystem. The question is, can those visionary farmers and allies work fast enough for us all? Will the capitalist mode of power have sabotaged more democratic, socially just and ecologically sustainable alternatives to the extent that we will lack the resilience needed to build a better food system?

\footnotetext{
${ }^{1}$ Based on USDA Natural Resource Conservation Services studies. See https://www.nrcs.usda.gov/wps/portal/nrcs/detail/ne/newsroom/releases/?cid=NRCSEPRD386010

${ }^{2}$ See blog posts from the University of Missouri Integrated Pest Management Program at https://ipm.missouri.edu/IPCM/2017/7/Ag_Industry_Do_we_have_a_problem_yet/.

${ }^{3}$ See http://www.npr.org/2017/06/14/532879755/a-pesticide-a-pigweed-and-a-farmers-murder.

${ }^{4}$ ETC Group (2013) notes BASF is not a strong contender in the seed market itself, but maintains a great deal of seed research and is in partnership with the other five firms in new ventures.

${ }^{5}$ https://agfundernews.com/big-ag-turns-digital-ag-growth-ex-senior-dupont-exec-joins-farmers-edge-board.html ${ }^{6}$ See Successful Farming's Pork Powerhouses: Accessed on July 31, 2017 at http://www.agriculture.com/pdf/porkpowerhouses-2016.

7 "A production contract usually specifies in detail the production inputs to be supplied by the contractor, the quality and quantity of the particular commodity involved, the production practices to be used, and the manner in which compensation is to be paid to the producer." ((Kunkel and Peterson 2015) Forward contracting is an agreement to purchase livestock in advance of slaughter, where the base price is established by reference to prices on the Chicago Mercantile Exchange. See https://www.ams.usda.gov/market-news/livestock-poultry-and-grain-cattle-terms.

${ }^{8}$ Annual report on the pork industry by Successful Farming. Available http://www.agriculture.com/livestock/porkpowerhouses/pork-powerhouses-2016-glut-of-pigs.

${ }^{9}$ Statement by Wenonah Hauter, Executive Director of Food and Water Watch on June 26, 2017 regarding Amazon's acquisition of Whole Foods. https://www.foodandwaterwatch.org/news/amazon\%E2\%80\%99sacquisition-whole-foods-higher-prices-fewer-choices-consumers-and-more-profits

${ }^{10}$ CNBC : https://www.cnbc.com/2017/06/16/amazon-whole-foods-pair-up-signals-power-shift-for-the-foodindustry.html

${ }^{11}$ https://www.ers.usda.gov/data-products/food-expenditures/interactive-chart-food-expenditures/
} 
${ }^{12}$ Bloomberg Government Disclosure, "US Foods Holding Corp at Deutsche Bank Global Consumer Conference Final." June 14, 2017.

${ }^{13}$ More information on these workshops, including full transcripts of each workshop, can be found at

https://www.justice.gov/atr/events/public-workshops-agriculture-and-antitrust-enforcement-issues-our-21st-centuryeconomy-10.

${ }^{14}$ See http://www.dominalaw.com/documents/Domina-Speech-Annual-OCM-Meeting-8-09.pdf.

${ }^{15}$ USDA announces Farmer Fair Practices Rule: https://www.usda.gov/media/press-releases/2016/12/14/usdaannounces-farmer-fair-practices-rules-clarifications-industry

${ }^{16}$ See more about Tom Trantham's farm at http://www.sare.org/Learning-Center/Multimedia/Videos-from-the-

Field/Sustainable-12-Aprils-Dairy-Grazing.

${ }^{17}$ See more at http://ranchfoodsdirect.com/.

${ }^{18}$ See more at http://www.wifoodhub.com/about-wfhc/.

${ }^{19}$ See http://www.ipes-food.org/ for more information. In 2016, the group released "Unravelling the Food-Health Nexus" and "From Uniformity to Diversity", and in 2017 "Too Big to Feed". One author, Howard, is a member of this group.

${ }^{20}$ La Via Campesina is an international peasants movement representing over 200 million peasant farmers in 79 countries belonging to 164 different organizations. Their 2017 declaration says "We, the peasants, rural workers, landless, indigenous peoples, pastoralists, artisanal fisherfolk, rural women and other peoples who work in the countryside around the world, declare that we feed our people and build the movement to change the world (emphasis in original)." https://viacampesina.org/en/

${ }^{21}$ https://www.iss.nl/fileadmin/ASSETS/iss/Documents/Conference_presentations/ElizabethMpofu-ISS25 January 2014.pdf 


\section{References}

Allen, Patricia. 2008. " Mining for justice in the food system: perceptions, practices, and possibilities." Agriculture and Human Values 25:157-161.

Almås, Reidar, and Hugh Campbell. 2012. "Reframing Policy Regimes and the Future Resilience of Global Agriculture.” In Rethinking Agricultural Policy Regimes: Food Security, Climate Change and the Future Resilience of Global Agriculture, edited by Hugh Campbell and Reidar Almas, 285-300. doi:10.1108/S1057-1922(2012)0000018015.

Adjemian, Michael K., B. Wade Brorsen, Tina L Saitone, and Richard J Sexton. 2016. “Thinning Markets in U.S. Agriculture What Are the Implications for Producers and Processors?” Washington, D.C.: USDA Economic Research Service.

Aziz, Tariq, M. Aamer Maqsood, Shamsa Kanwal, Shahid Hussain, H. R. Ahmad, and M. Sabir. 2015. “Fertilizers and Environment: Issues and Challenges.” In Crop Production and Global Environmental Issues, edited by Khalid ehman Hakeem, 575-98. Cham: Springer International Publishing. doi:10.1007/978-3-319-23162-4_21.

Bartlett, Donald, and James Steele. 2008. “Monsanto’s Harvest of Fear.” Vanity Fair, April. Bichler, Shimshon, and Jonathan Nitzan. 2012. “The Asymptotes of Power.” Real-World Economics Review 60 (2): 18-53.

Bonanno, Alessandro. 2009. “Sociology of Agriculture and Food Beginning and Maturity: The Contribution of the Missouri School (1976-1994).” Southern Rural Sociology 24 (2): 29_ 47.

Breimyer, Harold F. 1965. Individual Freedom and the Economic Organization of Agriculture. Urbana, IL: University of Illinois Press.

Burger, Ludwig. 2016. “Digital Farming Could Spell Shake-up for Crop Chemicals Sector.” Reuters, May 4. http://www.reuters.com/article/us-farming-digital-idUSKCN0XV0KP.

Carolan, Michael. 2017. "Publicising Food: Big Data, Precision Agriculture, and CoExperimental Techniques of Addition.” Sociologia Ruralis 57 (2): 135-54. doi:10.1111/soru.12120.

Carstensen, Peter C. 2008. “ Buyer Power, Competition Policy, and Antitrust: The Competitive Effects of Discrimination among Suppliers.” Antitrust Bulletin 53 (20): 271-331.

—. Ioannis Lianos, Claudio Lombardi, and James M. MacDonald. 2016. “Competition Law 
and Policy and the Food Value Chain.” Concurrences Competition Law Review 1 (1-35). http://www.concurrences.com/en/review/issues/no-1-2016/on-topic/competition-law-andpolicy-and-the-food-value-chain.

Coleman-Jensen, Alisha, Matthew P. Rabbitt, Christain A. Gregory, and Anita Singh. 2016. "Household Food Security in the United States in 2015." Washington, D.C.: USDA Economic Research Service.

Connor, John, Richard Rogers, Bruce Marion and Willard Mueller. 1984. The Food Manufacturing Industries: Structure, Strategies, Performance and Policies. Lanham, MD: Lexington Books.

Constance, Douglas H. 2008. “The Southern Model of Broiler Production and Its Global Implications.” Culture and Agriculture 30(1):17-31.

— 2009. "AFHVS Presidential Address - The Four Questions in Agrifood Studies: A View from the Bus." Agriculture and Human Values 26 (1): 3-14. doi:10.1007/s10460-0089187-0.

Constance, Douglas H., Mary Hendrickson, Phillip H. Howard, and William D. Heffernan. 2014a. "Economic Concentration in the Agrifood System: Impacts on Rural Communities and Emerging Responses.” In Rural America in a Globalizing World: Problems and Prospects for the 2010s, edited by Connor Bailey, Leif Jensen, and Elizabeth Ransom, 1635. Morgantown WV: West Virginia University Press.

Constance, Douglas H., William H. Friedland, Marie-Christine Renard, and Marta Rivera-Ferre. 2014b. “The Discourse on Alternative Agrifood Movements.” In Alternative Agrifood Movements: Patterns of Convergence and Divergence, edited by Douglas H. Constance, Marie-Christine Renard, and Marta Rivera-Ferre, 3-46. Bingley, UK: Emerald Group Publishing Ltd.

Constance, Douglas H., Francisco Martinez and Gilberto Aboites. 2010. "The globalization of the poultry industry: Tyson Foods and Pilgrim's Pride in Mexico." Pp. 59-75 in From Community to Consumption: New and Classical Themes in Rural Sociological Research edited by Alessandro Bonanno, Hans Bakker, Raymond Jussaume, Yoshio Kawamura, Mark Shucksmith. Bingley UK: Emerald Group Publishing.

Cotterill, Ronald W. 2010. “Antitrust Economic Analysis in Food Marketing Channels: A Global Perspective.” Agricultural Economics 41 (November): 83-91. doi:10.1111/j.1574- 
0862.2010.00491.x.

Crespi, John M., Tina L. Saitone, and Richard J. Sexton. 2012. “Competition in U.S. Farm Product Markets: Do Long-Run Incentives Trump Short-Run Market Power?” Applied Economic Perspectives and Policy 34 (4): 669-95. doi:10.1093/aepp/pps045.

Degen, Ronald Jean and K. Matthew Wong. 2012. "An Examination of the Resource-Based Horizontal Acquisition Strategy of JBS -- the Biggest Meat Packer in the World." Proceedings of the New York State Economics Association. Vol 5: 37-46.

DeLind, Laura B. 2011. “Are Local Food and the Local Food Movement Taking Us Where We Want to Go? Or Are We Hitching Our Wagons to the Wrong Stars?” Agriculture and Human Values 28 (2): 273-83. doi:10.1007/s10460-010-9263-0.

De Schutter, O. 2010a. "Addressing Concentration in Food Supply Chains: The Role of Competition Law in Tackling the Abuse of Buyer Power." Report of the United Nations Special Rapporteur on the Right to Food.

http://www.srfood.org/images/stories/pdf/otherdocuments/20101201_briefing-note03_en.pdf - 2010b. Agribusiness and the right to food.” Report to the United Nations Special Rapporteur on the Right to Food to the Human Rights Council http://www.srfood.org/images/stories/pdf/officialreports/20100305_a-hrc-1333_agribusiness_en.pdf

Desmarias, Annette. 2007. La Via Campesina: Globalization and the Power of Peasants. Chicago: University of Chicago Press.

—. 2017. "The power and potential of food sovereignty: an agenda for social transformation." Keynote Address to XXVII Congress of the European Society for Rural Sociology. Krakow, Poland. July.

Desmarias, Annette, A. Marta G. Rivera-Ferre, and Beatriz Gasco. 2014. "Building Alliances for Food Sovereignty: La Vía Campesina, NGOs, and Social Movements." Pp. 89-110 Alternative Agrifood Movements: Patterns of Convergence and Divergence, Research in Rural Sociology and Development, Volume 21 edited by Douglas H. Constance, Marie-Christine Renard, Marta G. Rivera-Ferre. Bingley, UK: Emerald Group Publishing Limited.

Eller, Donnelle. 2014. “Erosion Estimated to Cost Iowa \$1 Billion in Yield.” Des Moines 
Register, May 3.

http://www.desmoinesregister.com/story/money/agriculture/2014/05/03/erosion-estimatedcost-iowa-billion-yield/8682651/.

ETC Group. 2013. "Putting the Cartel before the Horse ... and Farm, Seeds, Soil, Peasants, Etc.” Communiqué, no. 111: 40.

FAO. 2009. How to Feed the World in 2050. Rome, Italy. Retrieved from http://www.fao.org/fileadmin/templates/wsfs/docs/expert_paper/How_to_Feed_the_World_i n_2050.pdf

2015. "Status and Trends of Animal Genetic Resources." In The Second Report on the State of the World's Animal Genetic Resources for Food and Agriculture, 25-42. Rome: FAO. http://www.fao.org/3/a-i4787e.pdf.

Fairbairn, Madeleine. 2012. " Framing transformation: the counter-hegemonic potential of food sovereignty in the US context." Agriculture and Human Values 29(2):217-230.

Farm Futures. 2017. “GIPSA Rule Implementation Delayed, Comment Period Extended,” February 8. http://www.farmfutures.com/farm-policy/gipsa-rule-implementation-delayedcomment-period-extended.

Foer, Albert A. 2016. “Abuse of Superior Bargaining Position (ASBP): What Can We Learn from Our Trading Partners?” Washington, D.C.: American Antitrust Institute.

Food and Water Watch; 2013. "Grocery Goliaths: How Food Monopolies Impact Consumers."

Washington, D.C. December. Available at

https://www.foodandwaterwatch.org/sites/default/files/Grocery\%20Goliaths\%20Report\%20 Dec\%202013.pdf.

Foster, John Bellamy, and Fred Magdoff. 2000. "Liebig, Marx and the Depletion of Soil Fertility: Relevance for Today’s Agriculture.” In Hungry for Profit: The Agribusiness Threat to Farmers, Food and Environment, edited by John Bellamy Foster, Fred Magdoff, and Frederick H. Buttel, 43-60. New York: Monthly Review Press.

Fuglie, Keith O., Paul W. Heisey, John L. King, Carl E. Pray, Kelly Day-Rubenstein, David Schimmelpfennig, Sun Ling Wang, and Rupa Karmarkar-Deshmukh. 2011. "Research Investments and Market Structure in the Food Processing, Agricultural Input, and Biofuel Industries Worldwide." Washington, D.C.: USDA Economic Research Service. 
Gardner, Brian. 2009. Global Food Futures: Feeding the World in 2050. London and New York: Bloomsbury Academic.

GIPSA. 2016. "Packers and Stockyards Program Annual Report.” Washington D.C.: USDA. https://www.gipsa.usda.gov/psp/publication/ar/2016_psp_annual_report.pdf.

Goldschmidt, Walter. 1978. As You Sow:Three Studies in the Social Consequences of Agribusiness. Montclair, NJ: Allenheld, Osmun and Co. Publishers Inc.

Greene, Joel L. 2016. “USDA’s ‘GIPSA Rule’ on Livestock and Poultry Marketing Practices.” R41673. Washington, D.C.: Congressional Research Service.

Gullickson, Gil. 2017. “Why Bayer’s Buyout of Monsanto Will Likely Proceed.” Successful Farming. March 17. http://www.agriculture.com/news/crops/why-bayer-s-buyout-ofmonsanto-will-likely-proceed.

Gura, Susanne. 2007. "Livestock Genetics Companies Concentration and Proprietary Strategies of an Emerging Power in the Global Food Economy.” Ober-Ramstadt, Germany. http://www.mdpi.com/2071-1050/1/4/1266/.

Harris, Wylie. 2004. “The Power of Concentration: Local Ruminations on Global Ruination.” The Touchstone. https://www.iatp.org/files/Power_of_Concentration_Local_Ruminations_on_Gl.htm.

Heffernan, William D. 1984. "Constraints in the Poultry Industry.” Pp. 237-260 in Research in Rural Sociology and Development: Vol 1., edited by H. Schwarzweller. Greenwich: JAI Press.

— 2000. "Concentration of Ownership in Agriculture.” Pp. 61-76 in Hungry for Profit: The Agribusiness Threat to Farmers, Food, and the Environment, edited by F. Magdoff, J.B. Foster and F.H. Buttel. New York: Monthly Review Press.

Heffernan, William D., Mary Hendrickson, and Robert Gronski. 1999. "Consolidation in the Food and Agriculture System.” Report to the National Farmers Union, Washington D.C. Hendrickson, Mary, William D. Heffernan, Philip H. Howard, and Judith B. Heffernan. 2001. "Consolidation in Food Retailing and Dairy.” British Food Journal 103 (10): 715-28. Hendrickson, Mary K., Harvey James, and William D. Heffernan. 2013. "Vertical Integration and Concentration in US Agriculture.” In Encyclopedia of Food and Agricultural Ethics, edited by Paul B. Thompson and David M. Kaplan, 1-10. Dordrecht: Springer Netherlands. doi:10.1007/978-94-007-6167-4_216-1. 
Hendrickson, Mary K. 2015. "Resilience in a Concentrated and Consolidated Food System.” Journal of Environmental Studies and Sciences 5 (3): 418-31. doi:10.1007/s13412-0150292-2.

Hendrickson, Mary K, and Harvey S James. 2005. "The Ethics of Constrained Choice: How the Industrialization of Agriculture Impacts Farming and Farmer Behavior.” Journal of Agricultural and Environmental Ethics 18 (3). Springer: 269-91.

Hendrickson, Mary, John Wilkinson, William D. Heffernan, and Robert Gronski. 2008. "The Global Food System and Nodes of Power.” SSRN Electronic Journal. doi:10.2139/ssrn.1337273.

Howard, Philip H. 2009. "Visualizing Food System Concentration and Consolidation.” Southern Rural Sociology 24 (2): 87-110.

Howard, Philip H. 2009. "Visualizing Consolidation in the Global Seed Industry: 1996-2008.” Sustainability 1 (4): 1266-87. doi:10.3390/su1041266.

_ 2015. "Intellectual Property and Consolidation in the Seed Industry." Crop Science 55 (6): 2489. doi:10.2135/cropsci2014.09.0669.

- 2016a. Concentration and Power in the Food System: Who Controls What We Eat? New York, NY: Bloomsbury Academic.

— 2016b. Decoding Diversity in the Food System: Wheat and Bread in North America. Agriculture and Human Values, 33(4): 953-960.

—. 2017. “Consolidation in Global Meat Processing.” Philhoward.net, June 21. https://philhoward.net/2017/06/21/consolidation-in-global-meat-processing/.

Ingram, Paul, Lori Qingyuan Yue, and Hayagreeva Rao. 2010. "Trouble in Store: Probes, Protests, and Store Openings by Wal-Mart, 1998-2007.” American Journal of Sociology 116 (1): 53-92.

Jaffee, Daniel, and Philip H. Howard. 2010. "Corporate Cooptation of Organic and Fair Trade Standards.” Agriculture and Human Values 27 (4): 387-99.

James Jr, Harvey S, Mary K Hendrickson, and Philip H Howard. 2013. "Networks, Power and Dependency in the Agrifood Industry." In The Ethics and Economics of Agrifood Competition, edited by Harvey S. James, 20:99-126. The International Library of Environmental, Agricultural and Food Ethics. Dordrecht: Springer Netherlands. doi:10.1007/978-94-007-6274-9. 
James Jr, Harvey S, and Mary K Hendrickson. 2008. "Perceived Economic Pressures and Farmer Ethics.” Agricultural Economics 38 (3). Wiley Online Library: 349-61.

King, Christine A .2008. "Community resilience and contemporary agri-ecological systems:

Reconnecting people and food, and people with people." Systems Research and Behavioral Science 25:111-124

Kirschenmann, Frederick L. 2015. "From Soil to Sustainability." Rootstalk: A Prairie Journal of Culture, Science and the Arts 2(1): 49-55.

Kloppenburg, Jack. 2010. “Impeding Dispossession, Enabling Repossession: Biological Open Source and the Recovery of Seed Sovereignty.” Journal of Agrarian Change 10 (3): 36788. doi:10.1111/j.1471-0366.2010.00275.x.

Kowitt, B Y Beth. 2017. “The Deal That Made an Industry Shudder.” Fortune. June 22.

Kunkel, Philip L., and Jeffrey A. Peterson. 2015. “Agricultural Production Contracts.” University of Minnesota Extension. Available at: https://www.extension.umn.edu/agriculture/business/taxation/farm-legal-series/agriculturalproduction-contracts/docs/agricultural-production-contracts.pdf.

Lamine, Claire. 2015. “Sustainability and Resilience in Agrifood Systems: Reconnecting Agriculture, Food and the Environment.” Sociologia Ruralis 55 (1): 41-61. doi:10.1111/soru.12061.

Leonard, Christopher. 2014. The Meat Racket. New York: Simon and Schuster.

Legun, Katharine, and Michael M. Bell. 2016. “The Second Middle: Conducers and the Agrifood Economy.” Journal of Rural Studies 48. Elsevier Ltd: 104-14. doi:10.1016/j.jrurstud.2016.10.004.

Levidow, Les. 2015. "European Transitions Towards a Corporate-Environmental Food Regime: Agroecological Incorporation or Contestation?" Journal of Rural Studies 40:76-89. Lianos, Ioannis, Dmitry Katalevsky, and Alexey Ivanov. 2016. “The Global Seed Market, Competition Law and Intellectual Property Rights: Untying the Gordian Knot.” Concurrences Competition Law Review II.

Lobao, Linda. 1990. Locality and Inequality: Farm Structure, Industry Structure, and Socioeconomic Conditions. Albany, NY: The State University of New York Press. Lobao, Linda, and Curtis W Stofferahn. 2007. “The Community Effects of Industrialized Farming: Social Science Research and Challenges to Corporate Farming Laws.” Agriculture 
and Human Values 25 (2): 219-40. doi:10.1007/s10460-007-9107-8.

Lowder, Sarah K., Jakob Skoet, and Terri Raney. 2016. “The Number, Size, and Distribution of Farms, Smallholder Farms, and Family Farms Worldwide.” World Development 87: 16-29. http://dx.doi.org/10.1016/j.worlddev.2015.10.041.

Lyson, Thomas A. 2004. Civic Agriculture. Lebanon, NH: Tufts University Press.

Lyson, Thomas A, George W Stevenson, and Rick Welsh. 2008. Food and the Mid-Level Farm. Cambridge MA: MIT Press.

MacDonald, James M. 2016. “Concentration, Contracting, and Competition Policy in U.S. Agribusiness.” Concurrences Competition Law Review I.: 3-9.

Marsden, Terry. 2012. “Towards a Real Sustainable Agri-Food Security and Food Policy: Beyond the Ecological Fallacies?” The Political Quarterly 83 (1): 139-45.

McMichael, Philip. 2009. "A Food Regime Genealogy." The Journal of Peasant Studies, 36, 139-169.

McMichael, Philip. 2014. "Historicizing food sovereignty." Journal of Peasant Studies 41(6): 933.

Montgomery, David R. 2012. Dirt: The Erosion of Civilization. Berkeley, CA: University of California Press.

Mooney, Pat. 2017. “Agricultural Mega-Mergers - History Lessons.” European Seed 4 (2). http://european-seed.com/agricultural-mega-mergers-history-lessons/.

Moss, Diana. 2016. “Consolidation in Agriculture and Food: Challenges for Competition Enforcement.” Concurrences Competition Law Review2 1: 10-14.

Mount, Phil. 2012. “Growing Local Food: Scale and Local Food Systems Governance.” Agriculture and Human Values 29 (1): 107-21. doi:10.1007/s10460-011-9331-0.

Murphy, Sophia, David Burch, and Jennifer Clapp. 2012. “Cereal Secrets: The World’s Largest Grain Traders and Global Agriculture.” Oxfam International. August. https://www.oxfam.org/sites/www.oxfam.org/files/rr-cereal-secrets-grain-tradersagriculture-30082012-en.pdf.

Murray, Alan. 2016. “Why Bayer Wants Monsanto.” Fortune, May 19. http://fortune.com/2016/05/19/bayer-monsanto-merger-approach-brainstorm/.

Olson, Mancur. 1965. The Logic of Collective Action: Public Goods and the Theory of Groups. Cambridge, MA: Harvard University Press. 
Oya, Carlos. 2013. “The Land Rush and Classic Agrarian Questions of Capital and Labour: A Systematic Scoping Review of the Socioeconomic Impact of Land Grabs in Africa.” Third World Quarterly 34 (9): 1532-57. doi:10.1080/01436597.2013.843855.

Peck, Alison. 2006. "State Regulation of Production Contracts." Available from the National Law Center, University of Arkansas. Available at: http://nationalaglawcenter.org/wpcontent/uploads/assets/articles/peck_contractregulation.pdf.

Plume, Kari. 2014. “High-Tech U.S. Farm Machines Harvest Big Data, Reap Privacy Worries.” Reuters, April 9. http://www.reuters.com/article/usa-farming-dataidUSL2N0N11U720140409.

Polansek, Tom, and Julie Zhu. 2017. “China’s WH Group Targets Beef and Poultry Assets in U.S. and Europe.” Reuters, June 6. http://www.reuters.com/article/us-smithfield-m-aidUSKBN18Z29Y.

Posey, Kirby G. 2016. “Household Income 2015: American Community Survey Briefs.” https://www.census.gov/content/dam/Census/library/publications/2016/demo/acsbr1502.pdf.

Rivera-Ferre, Marta G. 2012. "Framing of agri-food research affects of the analysis of food security: The critical role of the social sciences." International Journal of Sociology of Agriculture and Food, 19(2):162- 175.

Roesch-McNally, Gabrielle E., Andrea D. Basche, J.G. Arbuckle, John C. Tyndall, Fernando E. Miguez, Troy Bowman, and Rebecca Clay. 2017. “The Trouble with Cover Crops: Farmers’ Experiences with Overcoming Barriers to Adoption.” Renewable Agriculture and Food Systems, March, 1-12. doi:10.1017/S1742170517000096.

Rosset, Peter M., and María Elena Martínez-Torres. 2014. "Food Sovereignty and Agroecology in the Convergence of Rural Social Movements." Pp 137-157 in Alternative Agrifood Movements: Patterns of Convergence and Divergence edited by Douglas H. Constance , Marie-Christine Renard, Marta G. Rivera-Ferre. Bingley, UK:Emerald Group Publishing Limited.

Sinclair, Katrina, Allan Curtis, Emily Mendham, and Michael Mitchell. 2014. "Can Resilience Thinking Provide Useful Insights for Those Examining Efforts to Transform Contemporary Agriculture?” Agriculture and Human Values 31 (3): 371-84. doi:10.1007/s10460-0149488-4. 
Sito, Peggy. 2016. “Chinese Pork Giant WH Group May Eye Major Acquisitions by End of 2017.” South China Morning Post, November 20. http://www.scmp.com/business/companies/article/2047719/chinese-pork-giant-wh-groupwill-eye-major-acquisitions-end-2017.

Stuart, Diana. 2009. "Constrained Choice and Ethical Dilemmas in Land Management: Environmental Quality and Food Safety in California Agriculture.” Journal of Agricultural and Environmental Ethics 22 (1): 53-71. doi:10.1007/s10806-008-9129-2.

Stuart, Diana, and Rebecca L. Schewe. 2016. "Constrained Choice and Climate Change Mitigation in US Agriculture: Structural Barriers to a Climate Change Ethic.” Journal of Agricultural and Environmental Ethics 29 (3): 369-85. doi:10.1007/s10806-016-9605-z.

Taylor, C. Robert. 2007. "Legal and Economic Issues with the Courts' Rulings in Pickett v. Tyson Fresh Meats, Inc., a Buyer Power Case.” Washington, D.C.: American Antitrust Institute.

Taylor, C. Robert, and Diana Moss. 2013. “The Fertilizer Oligopoly: The Case for Global Antitrust Enforcement.” Washington, D.C.: American Antitrust Institute. http://www.antitrustinstitute.org/sites/default/files/FertilizerMonograph.pdf.

Thompson, Paul. 2010. The Ethics of Intensification: Agricultural Development and Social Change. New York: Springer.

U.S. Departments of Justice and Agriculture. 2010. Public Workshops Exploring Competition Issues in Agriculture. Ankeny, IA. March 12. Available at: https://www.justice.gov/sites/default/files/atr/legacy/2010/12/20/iowa-agworkshoptranscript.pdf

U.S. Department of Justice. 2012. "Competition and Agriculture: Voices from the Workshops on Agriculture and Antitrust Enforcement in Our 21st Century Economy and Thoughts on the Way Forward,” no. May: 1-24. https://www.justice.gov/sites/default/files/atr/legacy/2012/05/16/283291.pdf.

UNCTAD. 2006. "Tracking the Trend towards Market Concentration: The Case of the Agricultural Input Industry.” Geneva, Switzerland. http://unctad.org/en/Docs/ditccom200516_en.pdf.

USDA. 2015a. "Census of Agriculture Highlights: Family Farms." https://www.agcensus.usda.gov/Publications/2012/Online_Resources/Highlights/NASS 
Family Farmer/Family_Farms_Highlights.pdf.

- 2015b. "Principal Farm Operator Household Finances, by ERS Farm Typology." https://www.ers.usda.gov/webdocs/DataFiles/48870/table02.xls?v=42704.

Wilkinson, John. 2006. “Network Theories and Political Economy: From Attrition to Convergence? .” Research in Rural Sociology and Development 12: 27.

Wittmann, Hannah, Annette Aurélie Desmarais, and Nettie Wiebe. 2010. “The Origins \& Potential of Food Sovereignty.” In Food Sovereingty - Reconnecting Food, Nature \& Community, edited by Annette Desmarais, Nettie Wiebe, and Hannah Wittman. Oxford, UK. https://foodfirst.org/wp-content/uploads/2014/01/Food-Sovereignty_INTRO_OriginsPotential-of-Food-Sov.pdf.

Wu, S. Y., and J MacDonald. 2015. "Economics of Agricultural Contract Grower Protection Legislation.” CHOICES Magazine. 